\title{
Beyond Stationarity: Influence of Flow History and Sediment Supply on Coarse Bedload Transport
}

\section{P. W. Downs ${ }^{1}$ and P. J. Soar ${ }^{2}$}

${ }^{1}$ University of Portsmouth, previously University of Plymouth. ORCID: 0000-0002-2186-6394

${ }^{2}$ University of Portsmouth. ORCID: 0000-0001-7334-7046

Corresponding author: Peter Downs (peter.downs@port.ac.uk)

\section{Key Points:}

- Five-years of 5-minute passive monitoring displays highly variable bedload transport and sub-barfull effective discharge

- A two-phase sediment rating curve is revealed with a variable 'bulge' conditioned by sediment supplies during effective in-bank flows

- Coarse bedload supply is sensitive to the duration of competent flows, the volume of near-threshold flows and wetness of the previous year 


\begin{abstract}
Understanding how river bedload responds to climate and land use changes and water resource management initiatives is critical in developing sustainable approaches to river management. Passive monitoring techniques permit investigation of inter-annual dependencies in bedload transport in high resolution, including sediment supply factors. Here, seismic impact plate records are processed using a probabilistic model (BLIP) to derive a 5-year bedload dataset at 5minute intervals for the lower River Avon, Devon, UK. For water years that range from very dry to very wet, annual coarse bedload yields are estimated to vary through two orders of magnitude with wide prediction intervals. The most effective discharge occurs consistently at about onethird of bankfull flow, morphologically at 'sub-barfull' stage, the result of hysteretic trends and falling limb transport in this non-threshold channel. A two-phase sediment rating curve is revealed with a variable supply-related 'bulge' during in-bank flows, giving way to a near-linear trend during overbank flows. The supply-related component is predicted well using a sensitivitystyle metric that combines the cumulative duration of competent flows with the magnitudeduration product of near-threshold flows, defining a field-scale exemplar of 'stress history'. Further, the relative proportion of supply-related coarse bedload yield relates strongly to the relative wetness of the previous year. High resolution, multi-year data reveal that controls on bedload dynamics are unique to a site's hydrogeoclimatic context and position in the river basin. Passive monitoring holds promise for generating 'type sites' of bedload behavior critical for use in improving aquatic biodiversity and the sustainability of river management.
\end{abstract}

\title{
Plain Language Summary
}

Understanding sediment transported along a river's bed ('bedload') is critical in managing rivers to be resilient to environmental changes. Passively monitoring river bedload, here using seismic records of particles moving across steel plates, can generate high-resolution data sets over longer periods than possible using active sampling. In the lower River Avon, Devon, UK, wet years carried two orders of magnitude more bedload than dry years, with peak loads of sediment transported after the bank-overtopping flows, rather than during them. This implies that bedload is controlled by the supply of sediment in addition to the flow energy available for transport, which has been the focus of most research. Analysis demonstrates that the supply-related bedload component is larger in wetter years and described well by dividing the total period of moderately high, 'sediment mobilizing' flows by the volume of lower flows that 'vibrate' the riverbed into a more stable configuration. Annually, supply-related bedload also relates well to how much wetter the previous year was than the current year, indicating that in dry years, locally available supplies are critical for transport. High resolution, multi-year data suggest that bedload transport has multiple controls, requiring site-specific datasets to benefit management approaches. 


\section{Introduction}

With scenarios for climate change indicating a global increase in extremes of weather and runoff (e.g., Goodess, 2013; Yin et al., 2019) in conjunction with additional socio-economic vulnerability to flooding (e.g., Hall et al., 2003), it is profoundly important to understand the impact of climate variability on the dynamics of environmental systems that exhibit non-linear behavior. In river systems, fulfilling a sustainability imperative in management requires measures not just to ensure the climate-resilience of the current system, but also to offset the huge losses in biodiversity and ecosystem services resulting from earlier land use changes and water resource management initiatives (e.g., Downs \& Piégay, 2019; MEA, 2005; WWF, 2016). Sustainable approaches to river management require the integration of best-practice approaches to land and water quality management, measures that ensure or reinstate the lateral and longitudinal hydro-sedimentological connectivity of fluvial systems, and methods to conserve or restore highly heterogenous and dynamic river morphologies (e.g., Beechie et al., 2010; Downs \& Gregory 2004, Roni \& Beechie 2013; Wohl et al., 2005, 2015). The latter provides the physical 'template' for fluvial habitats that underpin aquatic biodiversity and requires a good understanding of the ways that river bedload promotes and regulates morphological heterogeneity in semi- and fully-alluvial river channels. Accurate knowledge of the controls on bedload transport rates is thus critical in understanding how channel morphology will respond to changing climate, land uses and resource management.

Bedload transport has long been regarded as an energetic phenomenon, controlled primarily by shear stresses generated by river discharge. Such focal concern for energetic controls on transport stem from seminal perspectives on sediment transport capacity introduced by Gilbert, Einstein and Bagnold (Wainwright et al., 2015), reinforced by laboratory experiments focused on the hydraulic forces required to entrain generally well-sorted or uniform grain size mixtures (see Buffington \& Montgomery, 1997), and perpetuated by associating 'capacity-based' bedload equations with stream channel equilibrium (Wainwright et al., 2015). However, capacity-based equations inherently over-estimate sediment load, potentially by an order of magnitude or more, even in 'sediment rich' environments (e.g., Gomez, 2006; Gomez \& Church, 1989) and are better conceived as estimates of maximum possible transport rate (Gao, 2011). Further, field monitoring has long indicated that bedload is subject to significant hysteresis and pulsing during the passage of flood hydrographs (Reid et al., 1985; see also Emmett, 1975; Hooey, 1992; Nicholas et al., 1995). This evidence implies that, beyond energetic features, such as slope variation (Mueller et al., 2005; Lamb et al., 2008), regional and local sediment supply factors must contribute important absolute and relative controls (respectively) on bedload transport rates (Barry et al., 2004; Pfeiffer et al., 2017). In response, attempts have been made to integrate into predictive equations factors related to the 'hiding function' provided by bed material texture (e.g., Wilcock and Crowe, 2003) and the impact of supply-reductions related to channel armoring (Barry et al., 2004), and to define the state-dependence of critical shear stress (Johnson, 2016). Assessments have also been made on the performance of bedload transport equations under supply-limited conditions (Bravo-Espinosa et al., 2003) and equations developed that 
incorporate the reach-scale volume of available sediment for use in applications such as dam removal modeling (Cui \& Wilcox, 2008).

Acknowledging the importance of sediment supply factors introduces significant extrinsic controls on rates of bedload transport. First-order, supra-catchment controls on coarse sediment production related to geological structure, lithology, topography, tectonics and land use set the 'process domain' (Montgomery, 1999) and influence sediment pathways (Borselli et al., 2008; Carvalli et al., 2013). Second-order, network controls determine sediment supply connectivity (e.g., Fryirs, et al., 2007) and include the influence of human activities and the character of highflow events that drive longitudinal processes and link hillslopes to rivers through partial area concepts (Fryirs, 2013). Tertiary level controls at the reach scale dictate sediment supply and storage and influence downstream sediment connectivity (Hooke, 2003); this includes the structure of the channel bed as a control on the delivery of sediment to a singular location, a scale at which variations in supply are usually cast in terms of sediment availability or mobility. Related to bed structure controls, evidence for bedload hysteresis and pulsing indicate additional intrinsic controls on sediment dynamics related to various modes of self-organization of bed particles and which can increase the critical Shields stress for entrainment by a factor or two or more (Church, 2010). Such intrinsic controls include surface grain size distribution, the influences of hydrograph shape on the propensity for bed armoring (Hassan et al., 2006; Mao, 2012), the sequencing and duration of high magnitude events on sediment entrainment rates (Papangelakis \& Hassan, 2016) and the duration and magnitude of near-critical flows preceding sediment entrainment (Haynes \& Pender, 2007; Mao, 2018; Masteller \& Finnegan, 2017; Masteller et al., 2019; Ockelford \& Haynes, 2013; Ockelford et al., 2019). The 'stress history' implied by near-critical flows is also proposed as a correction factor in bedload transport formulae (Mao, 2012; Monteith \& Pender 2005; Paphitis \& Collins, 2005). All of these factors imply the influence of spatio-temporal controls on sediment 'supply' (broadly defined) to account for observed variabilities in predicted and measured bedload transport rates.

Most studies considering temporal factors have employed controlled flume experimentation, for example those related to stress history (citations above) and the effects of sediment supply variability (e.g., Elgueta-Astaburuaga \& Hassan, 2017, 2018, 2019). In part, this is because bedload data collection has historically been limited to 'active' approaches that are intrusive, expensive and potentially dangerous (Gray, 2002). However, recent adoption of passive, high resolution methods for estimating river bedload (reviews in Gray, 2010a; Rickenmann, 2017) offer a fundamentally novel means of investigating spatio-temporal dependencies in bedload transport with the potential of more accurately accommodating the various competing extrinsic and intrinsic controls on reach-scale sediment dynamics. By pairing devices such as geophones, hydrophones and impact plates to miniaturized data loggers, such advances enable extension of both resolution and duration of bedload data collection - safely, cheaply and non-intrusively. In bringing bedload data into the realm of 'big data', new challenges arise related to the empirical 'noise' associated with such large data volumes (e.g., Downs et al., 2016; Rickenmann et al., 
2012), but it also facilitates the development of data-driven estimates of bedload rates that are uncertainty-bounded (Soar \& Downs, 2017) and, critically, do not inherently over-predict. With lengthy monitoring periods, it becomes possible to investigate inter-annual variations in bedload transport (Aigner et al., 2017; Masteller et al., 2019; Rickenmann, 2018, 2020), thus increasing the prospect of better understanding cause and effect in controls on bedload transport and predicting future yields under conditions of changing hydroclimates.

Extending from earlier research (Downs et al., 2016; Soar \& Downs, 2017; Downs \& Soar, 2018), this investigation seeks to test the assumption of inter-annual stationarity intrinsic to coarse sediment rating curves for a relatively flashy, perennial, gravel-bed river in Devon, UK. High-resolution measurements extending over five Water Years allow assessment of the relative significance of energetic limitations versus flow history and factors influencing sediment supply. While this is important for better understanding network- to reach-scale controls on sediment transport dynamics and for gauging the influence of particularly wet or dry years on sediment yields, the aim here is applied rather than experimental, specifically, whether a simple metric can be derived to characterize supply factors influencing inter-annual variability in coarse bedload transport rates. Identifying such a metric would contribute towards the call for more accurate but low effort methods of bedload estimation that are both meaningful and practical (Wilcock, 2001) and, more broadly, would assist in articulating the implications of climatic variability on fluvial system response that is relevant for meeting channel stability, flood risk and biodiversity objectives of sustainable river management.

\section{Study Context}

This research is based on five Water Years (WY) of seismic impact plate data collected from a three-plate array located at a cross-section in the lower River Avon, Devon, UK (catchment area $110 \mathrm{~km}^{2}$ ). The years range from very dry to some of the wettest on gauged record (38 years). The predominantly rural Avon rises in Dartmoor National Park (elevation $460 \mathrm{~m}$ ) and flows approximately $40 \mathrm{~km}$ to the sea. Average annual rainfall ranges from 2,200 $\mathrm{mm}$ in the headwaters to $1,000 \mathrm{~mm}$ at the coast. Avon Dam, constructed in 1959, is regularly overtopped in winter and regulates only $12 \%$ of the catchment at the gauging station situated $1.2 \mathrm{~km}$ upstream of the impact plates (Loddiswell: NRFA 46008) and is assumed to have little effect on downstream high flows. The monitoring site sits in a fully alluvial, actively meandering reach of the river in the lowest two kilometers of the catchment; the active channel bed width is $12.9 \mathrm{~m}$ (rather narrower than sites upstream and downstream) and has a bed slope of 0.0041 . Water surface slope at bankfull is 0.0023 . Sediment samples indicate a median surface grain size of 33 $\mathrm{mm}$ and a median sub-surface grain size of $15 \mathrm{~mm}$, with frequent gravel mobility suggested by convergence of surface and bulk grain size at $\approx \mathrm{D}_{60}$ (further details in Downs et al., 2016).

The igneous granite of the upper catchment results in naturally low rates of coarse sediment production, except where historical placer mining occurred (Bradley, 1990). As such, a matrix 
172 overlay of topography (hillslope angle) and geology (lithology), derived from the method of

173 Booth et al. (2014), suggests that, historically, catchment sediment production was probably

174 focused in the middle and lower reaches of the catchment where relatively more erodible slates,

175 shales and grits combine with steep-sided valleys (Figure 1). However, the paucity of active

176 landslides in the catchment suggests that, placer mining deposits apart, contemporary coarse

177 sediment sources derive primarily from legacy deposits in eroding riverbanks, and possibly via

178 the connectivity provided by 'sunken lanes' (see Boardman, 2013). Locally, the site's floodplain

179 is composed of abundant gravels and cobbles in basal bank sediments that break sharply to silty

180 loams in the upper layers. The upper surface likely formed in response to significant fine

181 sediment discharges resulting from intensive tin mining in the upper catchment during the 15th

182 and 16th centuries AD or earlier (Thorndycraft et al., 2004). The river planform near the

183 monitoring site is undergoing meander extension and transformation, but the impact plate array

184 is situated at an inflection point that has been static since monitoring began.

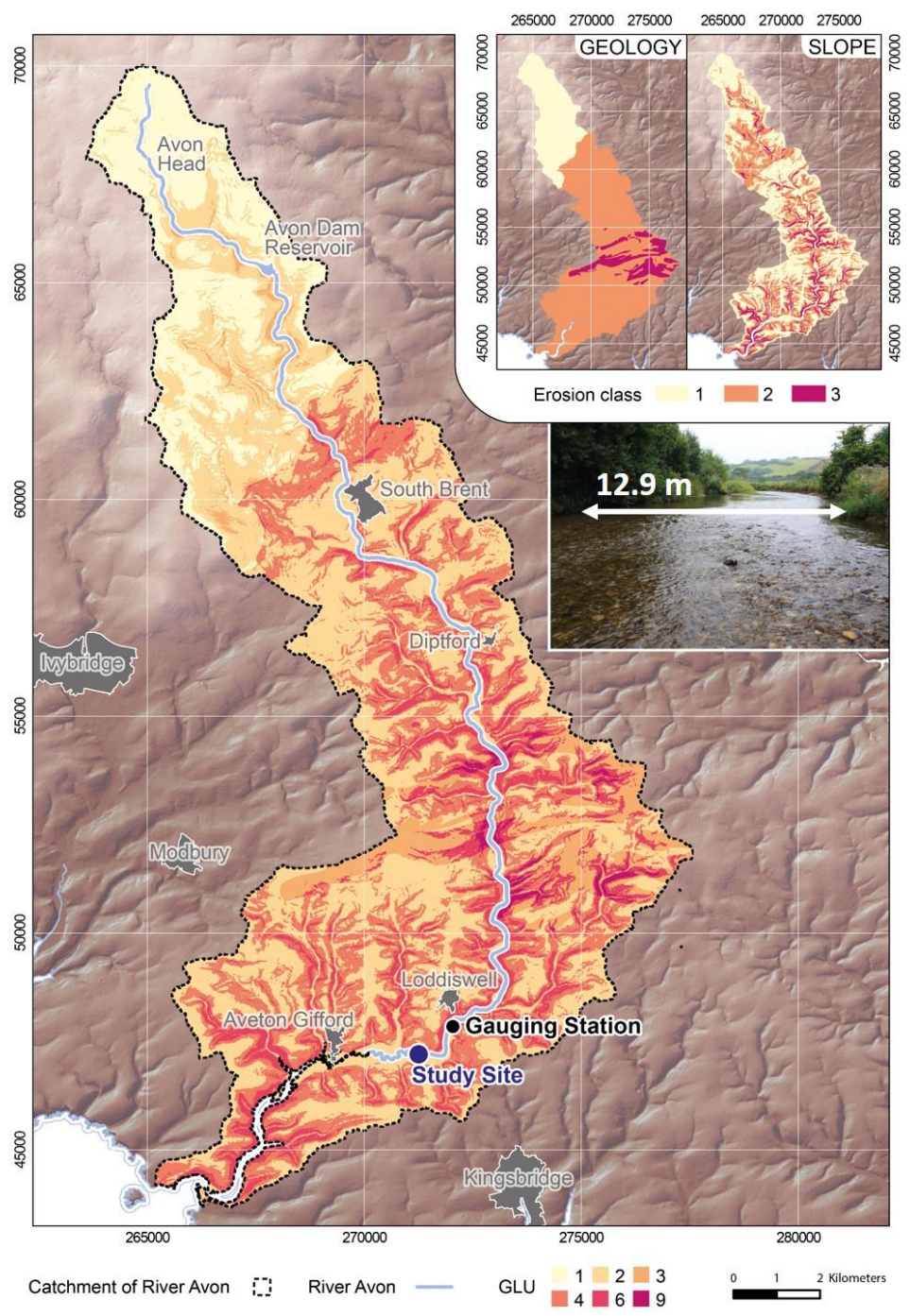


Figure 1: Geospatial characteristics of potential sediment production in the River Avon watershed based on a hillslope-lithology overlay (derived from the 'Geomorphic Landscape Unit' [GLU] method of Booth et al. 2014; this application modified from Twohig, 2014). Geology classes: 1) granites; 2) metamorphic and slates; 3) sandstone. Slope classes (degrees) using natural breaks in slope distribution: 1) 0-6.81;2) $6.82-15.03 ; 3)>15.03$. Higher number classes are more erodible; classes combine to provide GLUs with erodibility scores of 1-9. The importance of sediment sources from the middle and lower watershed is highlighted (deeper shades). The inset photograph is taken from the monitoring cross-section looking upstream during very low flow.

\section{Methods}

A near-continuous record of the start, end and relative intensity of coarse bedload transport was recorded using three 'Benson-type' seismic impact plates equally spaced across the channel cross-section. The devices consist of a $150 \times 130 \times 6 \mathrm{~mm}$ steel top plate, an accelerometer to convert the mechanical energy of the particle strike into an electrical impulse, and a Tinytag data logger (details in Downs et al., 2016, and Richardson et al., 2003 for an earlier design). Plates are installed flush to the channel bed, mounted on a $400 \mathrm{~mm}$ x $400 \mathrm{~mm}$ paving slab for stability, and have been modified using an extended cable to allow in-situ data download. Pre-installation drop tests indicated that impacts are recorded across the extent of the paving slab (with some presumed reduction in recording efficacy near the edges, see below), effectively broadening the size of the impact plate. Field evidence and various controlled experiments suggest that the minimum reliably detected particle size is $\approx 10 \mathrm{~mm}$ which occurs at flows of $\approx 4 \mathrm{~m}^{3} \mathrm{~s}^{-1}$ at the site (manufacturer data; Downs et al., 2016, respectively). The plates were set to record over 2.5minute intervals with a maximum frequency of $5 \mathrm{~Hz}$ to reduce the effect of multiple counts from rolling particles. While seismic sensor recordings vary as a function of particle impact location, shape, size, mode of transport, and energy transmitted to the plate (summarized by Wyss et al., 2016a), a growing body of calibration data confirms that impacts provide a reasonable estimate of particle transport (e.g., Barriere et al., 2015; Kuhnle et al., 2017; Wyss et al., 2016a, 2016b, 2016c).

Flow depths near the plates were recorded using a submersible pressure transducer, while surface and sub-surface particle size distributions were established using multiple particle counts (Wolman, 1954) and bulk samples, respectively. Supplementary pressure transducers were installed upstream and downstream of the site during winter 2013-14 to provide measurements of water surface slope at varying flow discharges. Sediment dynamics resulting from the notable wet first season of monitoring are detailed by Downs et al. (2016).

As impact plates record the intensity of coarse bedload transport but not the particle size, Soar and Downs (2017) developed a data-driven, uncertainty-bound, probabilistic method for converting particle counts into rates of bedload. The BedLoad from Impact Plates model (BLIP) represents an approach to bedload estimation that combines attributes of particle monitoring (the 
impact plates) and sediment transport theory with the addition of a probabilistic element provided by a Monte Carlo simulation to account for the inherent stochasticity of coarse sediment transport and to avoid needing grain-size specific calibration of the impact plates. For each record (aggregated to 5-minute intervals to increase computational efficiency), the Monte Carlo component converts individual count data into a probabilistic array of possible particle sizes in transit using knowledge of (1) the minimum detectable particle size, (2) the particle size distribution of the upstream channel bed and (3) concomitant local flow elevations to establish boundary shear stress above each plate (for details, see Soar \& Downs, 2017). Since the estimate uses data from the impact plates, it is moderated autogenically for the influence of sediment availability, providing a location-specific estimate that, unlike, capacity-based sediment transport equations, is not intrinsically prone to overestimation. Before each run, the impact count data are used to calibrate the model internally, which involves optimizing for the largest particle in motion at any individual flow against the Shields parameter and sediment hiding coefficient, both of which can be varied between set limits (Soar \& Downs, 2017). Here, optimum calibration for a minimum detectable particle size of $10 \mathrm{~mm}$ at $4 \mathrm{~m}^{3} \mathrm{~s}^{-1}$ was achieved by setting the Shields parameter to 0.03 (the mid-range value of Mueller et al., 2005) and the hiding factor to 0.6 (the mid-range value of Ferguson, 2005). Stochastic uncertainties in rate estimates were achieved by randomly varying the minimum particle detection size from 8-12 mm, Shields parameter from $0.025-0.035$, hiding factor from $0.5-0.7$ and particle specific gravity from $2.55-$ 2.75. Water surface slopes were variable with discharge and ranged from 0.0030 at low flows to 0.0250 during overbank flows based on field data from pressure transducers.

Overall, this method assumes that: one impact is recorded by each particle, the likelihood of particle count underestimation is canceled by the likelihood of overestimation, the gradation of bed material remains relatively constant over time, and the inclusion of a probabilistic element provides an estimate of uncertainties that are faithful to the stochastic nature of bedload transport. The result is a data-driven, uncertainty-bound, indicative range of bedload estimates that vary over time with the same resolution as the impact plate settings.

\section{Results: implications of using long-term, high-resolution data to characterize coarse sediment transport}

Bedload transport rates have long been observed to possess significant short-term variability (i.e., hysteresis, pulsing) but high-resolution active bedload measurements have often been limited to single-event timescales (e.g., Bunte et al., 2004; Garcia et al., 2000; Habersack et al., 2001; Reid et al., 1985; Vericat \& Batalla, 2010). In contrast, passive monitoring of coarse bedload offers the prospect of long-term, high frequency bedload datasets and should minimize temporal 'aliasing' of data signatures that can result from coarse, short-term sampling (see also Masteller et al., 2019; Rickenmann, 2018). Critically, it allows examination of bedload transport over the full duration of (multiple) hydrographs. Results here highlight the hydrological context 
for the monitoring period, the subsequent estimation of coarse bedload transport rates using BLIP, the uncertainties revealed by high-resolution continuous data, and observations of the persistent dominance of bar-building flows on transport loads despite highly variable annual sediment yields.

\section{Hydrological context}

The three-plate array recorded impacts through five Water Years (WYs), 2013-2017, the hydrological character of which provides the fundamental driver for coarse sediment dynamics. Water year categorization is a useful tool in water resources management (e.g., Null \& Viers, 2013) and here provides critical context. Categorized via quintiles of annual flow volume (M $\mathrm{m}^{3}$ ) into flow year types ranging from Very Wet to Very Dry, the monitoring period encompassed three Very Wet years $(2013,2014,2016)$, one Dry (2015) and one Very Dry (2017) year (Table 1). Table 1 also highlights the volume of discharges likely to generate coarse bedload transport and respective peak discharge from each year. Additional resolution is provided by the annual flow duration curves in Figure 2.

\begin{tabular}{|c|c|c|c|c|c|c|}
\hline Water Year & $\begin{array}{c}\text { Annual } \\
\text { flow } \\
\text { volume }\end{array}$ & $\begin{array}{c}\text { Rank and } \\
\text { Category }^{\mathrm{b}}\end{array}$ & $\begin{array}{c}\text { Annual Flow } \\
\text { volume } \\
\mathrm{m}^{3} \mathrm{~s}^{-1 \mathrm{c}}\end{array}$ & $\begin{array}{c}\text { Rank and } \\
\text { Category }^{\mathrm{b}}\end{array}$ & $\begin{array}{c}\text { Instantaneous } \\
\text { peak discharge }\end{array}$ & $\begin{array}{c}\text { Recurrence } \\
\text { Interval (RI) }\end{array}$ \\
\hline 2013 & $\mathrm{M} \mathrm{m}^{\mathrm{d}}$ & & $\mathrm{M} \mathrm{m}^{3}$ & & $\mathrm{~m}^{3} \mathrm{~s}^{-1}$ & years \\
\hline 2014 & 153.6 & 5. Very Wet & 85.7 & 4. Very Wet & 103 & 25.0 \\
\hline 2015 & 160.5 & 3. Very Wet & 105.3 & 2. Very Wet & 59 & 2.0 \\
\hline 2016 & 107.3 & 24. Dry & 33.0 & 29. Dry & 43 & 1.2 \\
\hline 2017 & 95.3 & 6. Very Wet & 73.4 & 7. Very Wet & 54 & 1.6 \\
\hline Average $^{\mathbf{a}}$ & $\mathbf{1 1 8 . 0}$ & & 18.0 & 33 . Very Dry & 63 & 2.5 \\
\hline
\end{tabular}

Table 1: Hydrological characteristics of the monitored period, focusing on higher flows. Notes: a: average of entire gauging record (36 years, 38 years for instantaneous peaks), b: based on five-fold (20 percentile) sub-divisions, c: consistent flow at the threshold of coarse sediment transport (see Methods), d: derived from the Gumbel Extreme Value Type 1 distribution.

The Very Wet years were themselves quite variable. WY2013 included the second highest instantaneous discharge on record and by far the wettest 24-hour period on record, averaging $59.5 \mathrm{~m}^{3} \mathrm{~s}^{-1}$ and shown clearly in Figure 2 (0-6\% duration). WY2013 was also preceded by an exceptionally wet period during the latter part of WY2012 that included the instantaneous flow of record (124 $\mathrm{m}^{3} \mathrm{~s}^{-1}, 96$-year RI) and some quite extraordinary coarse sediment dynamics (see Downs et al., 2016). WY2014, in contrast, contributed only a 2.0-year RI event but included the wettest recorded period for flows in the $7-15 \mathrm{~m}^{3} \mathrm{~s}^{-1}$ range (7-26\% exceedance, Figure 2). This is critical as coarse sediment transport at the site begins in flows $>8 \mathrm{~m}^{3} \mathrm{~s}^{-1}$ and frequently peaks in the 11-12 $\mathrm{m}^{3} \mathrm{~s}^{-1}$ band (see below). WY2016 was Very Wet but contained far fewer large flow events. Contrasts in discharge distributions between the Very Wet years is clearly evident in Figure 2. WY2015 was Dry, and not far from Very Dry in terms of flow events $>8 \mathrm{~m}^{3} \mathrm{~s}^{-1}$, but constituted the closest to a 'normal' hydrological year during the monitoring period. Finally, 
WY2017 was both Very Dry overall and the fourth driest on record in terms of volumetric discharges $>8 \mathrm{~m}^{3} \mathrm{~s}^{-1}$, although it produced one 2.5-year RI event in November 2016. The paucity of high discharges is indicated clearly in Figure 3.

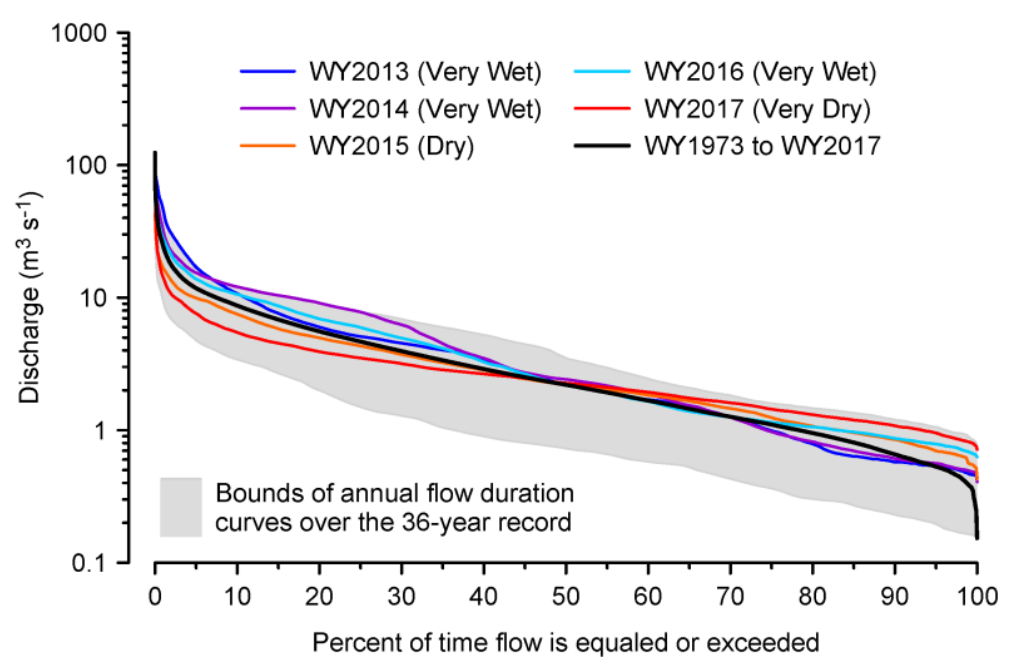

Figure 2: Flow duration curves (FDCs) from a 36-year record of gaged flows from the Environment Agency-operated gage at Loddiswell (NRFA 46008: 1973-1981, 1991-2017), processed using 15-minute discharge (method of Rosburg et al., 2017, based on Vogel and Fennessey, 1994). Annual FDCs for each Water Year (WY), 2013-2017, are compared against the FDC for the 36-year record. The shaded region indicates the bounds of annual FDCs over the period of record.

\section{Bedload estimates}

Resulting as a non-linear function of a highly varied hydrology, distinct differences arise in the estimated bedload yields over the monitoring period (Figure 3). Impact count data from the three-plate array are converted to a cross-section averaged bedload rate using the BLIP model. The individual 5-minute estimates represent the most probable bedload rate stemming from flow hydrology, hydraulics and recorded sediment impacts. While the time series depicts a visible correspondence of peakedness and duration of high flow events with bedload transport response, pulsing and hysteretic effects obscure this relation over shorter timeframes at this site, mirroring results from other high-resolution bedload studies (starting with Reid et al., 1985; see Downs et al., 2016: Figure 10 for hysteresis at this site). Such 'continuous' data emphasize the interannual variability inherent to cross-sectional bedload transport over the five years, essentially magnifying the variation in hydrology and ranging from the spartan record of transport during the Very Dry WY2017 to the intense response to the continuously high flows in winter WY2014 that provided uninterrupted transport for at least two months (we assume longer, but safety concerns precluded data download in that spring). 

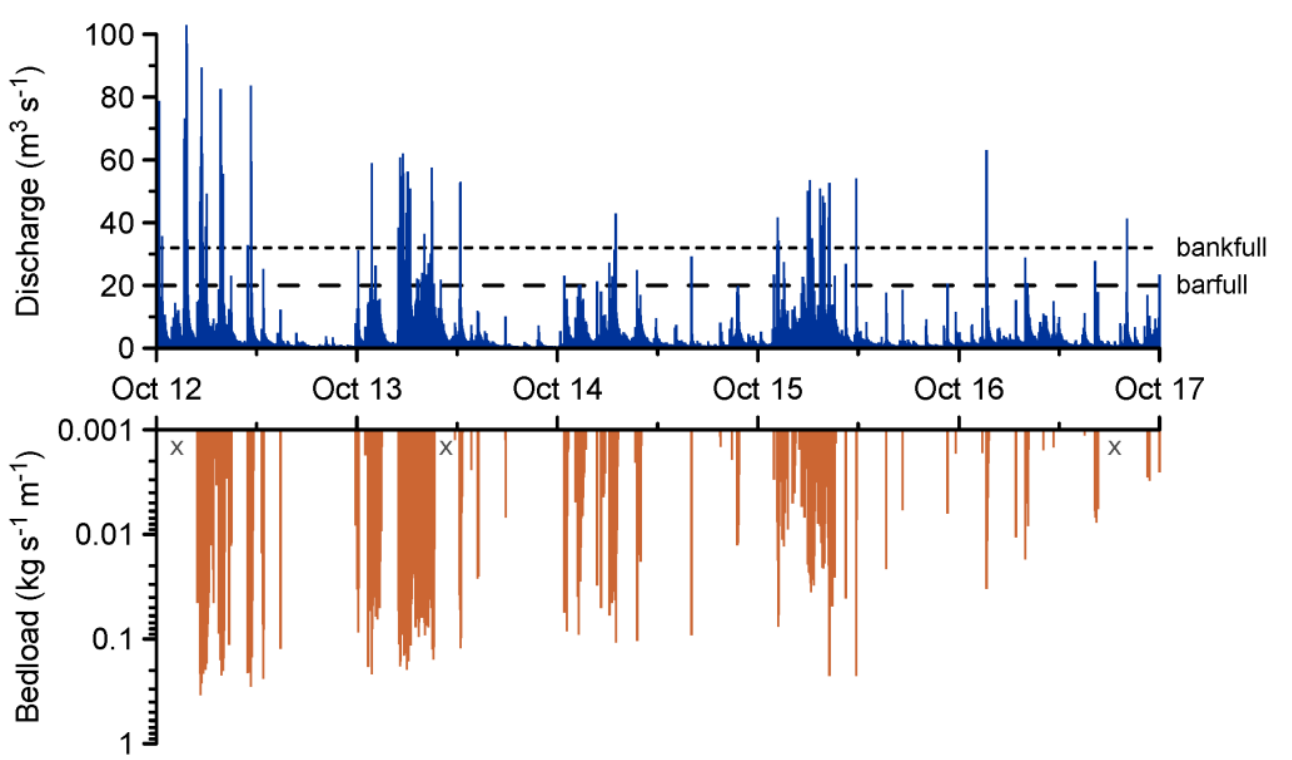

Figure 3: Time series of gaged 15-minute discharges (interpolated to 5-minute intervals) versus 5-minute cross-sectional bedload rates $(>10 \mathrm{~mm})$ obtained from $2 \times 2.5$-minute interval bedload counts aggregated from three seismic impact plates, relative to the width of the cross-section. Note: discharge axis is arithmetic, bedload axis is logarithmic; $\mathrm{x}=$ periods of no data from the impact plates; bedload is the geometric average of the BLIP Monte Carlo output distribution.

\section{Bedload dynamics, effective discharge and uncertainty}

Figure 4 emphasizes the short-timeframe scatter inherent to the relationship of 'instantaneous' (5-minute) cross-sectional bedload rate with discharge. For clarity, only non-zero bedload records are shown. Coarse bedload transport occurs across at least one of the plates for 5.5 to $30.6 \%$ (average 20\%) of time in individual years, emphasizing that the study period includes three of the wettest six years of record. Figure 4 also indicates the relationship of bedload discharge to the channel morphology, specifically where flow reaches bankfull and overtops the channel $\left(>32 \mathrm{~m}^{3} \mathrm{~s}^{-1}\right)$ and the monitored elevation of the flow that just submerges channel bars (i.e., 'barfull' flow, $20 \mathrm{~m}^{3} \mathrm{~s}^{-1}$ ). Bedload counts are recorded consistently for flows $\geq 8 \mathrm{~m}^{3} \mathrm{~s}^{-1}$. In all years the majority of bedload transport occurs in flows just below barfull such that there is no discernable linear or power trend through the entirety of the data. The effect is magnified during wetter years. Overall, the scatter evident from the multi-year period of high-resolution data (Figure 4f) provides sustained evidence that bedload transport rates are only partially explained by the shear stresses generated by instantaneous flows; clearly there are aspects relating to sediment supply and other factors that are of considerable influence, as explored later. 

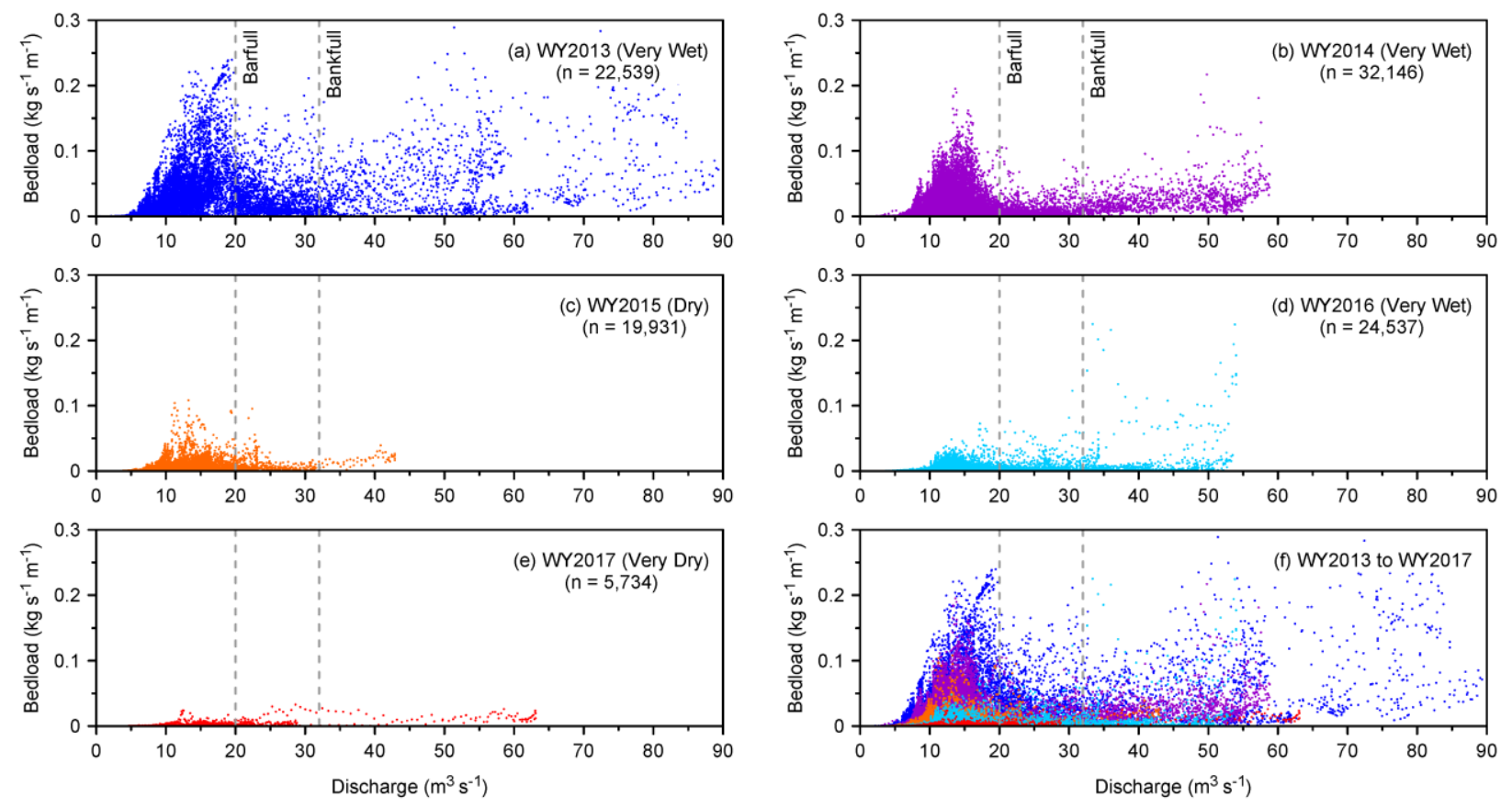

Figure 4: Scatter of 5-minute averaged discharge versus estimated rates of cross-sectional bedload for (a-

The two-dimensional nature of Figure 4 masks the 'depth' of the data cloud (e.g., >30,000 points in Figure 4b). This attribute of high-resolution studies potentially disguises the importance of individual flows in contributing to the annual and multi-annual bedload yield. To illustrate, Figure 5 aggregates data into uncertainty-bounded magnitude-frequency plots using $1 \mathrm{~m}^{3} \mathrm{~s}^{-1}$ flow intervals (method in Soar \& Downs, 2017). Despite highly variable annual bedload volumes (note different scales on y-axes), a pattern emerges wherein the most effective discharge (i.e., the flow transporting the largest component of the annual load, Andrews, 1980; see Soar and Thorne, 2011, for review of effective discharge methodology) for cross-sectional coarse bedload is consistently in the $8-20 \mathrm{~m}^{3} \mathrm{~s}^{-1}$ flow range (i.e., sub-barfull). Each plot is highly skewed with a long tail proportional to the magnitude of overbank flow received in individual years. Aggregated over the five years (Figure 5f), effective discharge peaks in the $11-12 \mathrm{~m}^{3} \mathrm{~s}^{-1}$ interval, transporting an average load of $78 \mathrm{t} \mathrm{yr}^{-1}$. It is influenced heavily by the peakedness of the Very Wet WYs 2014 (peak: 11-12 $\mathrm{m}^{3} \mathrm{~s}^{-1}$, estimated load of $244 \mathrm{t}$ ) and 2013 (peak 11-13 $\mathrm{m}^{3} \mathrm{~s}^{-1}$, averaging $135 \mathrm{t}$ ). The similar but bi-modal effective discharge during the Very Wet WY of 2016 has a low peak load ( $23 \mathrm{t}$ ) that reflects the relative paucity of high flow events. In the drier WYs of 2015 and 2017, the effective discharge is slightly lower $\left(9-11 \mathrm{~m}^{3} \mathrm{~s}^{-1}\right)$ and loads lower still 
(peak loads $20 \mathrm{t}$ and $1.4 \mathrm{t}$, respectively). Figure 5 includes the $75 \%$ and $95 \%$ prediction ranges associated with each flow interval. Such ranges result from the inherent variability in particle counts for individual discharges as simulated by BLIP model's probabilistic estimation of the most likely particle size in transit for each flow. The load associated with the most effective discharge in WY2014 (244 t) has a 95\% prediction interval ranging from 169-357 $\mathrm{t}$ while the commensurate interval associated with the most effective discharge over the 5-year data series (peak of $78 \mathrm{t} \mathrm{a}^{-1}$ ) ranges from 53-121 $\mathrm{t} \mathrm{a}^{-1}$. These values suggest caution in adopting 'average' measures and exemplify the potential uncertainty inherent in bedload datasets developed from short periods of measurement.
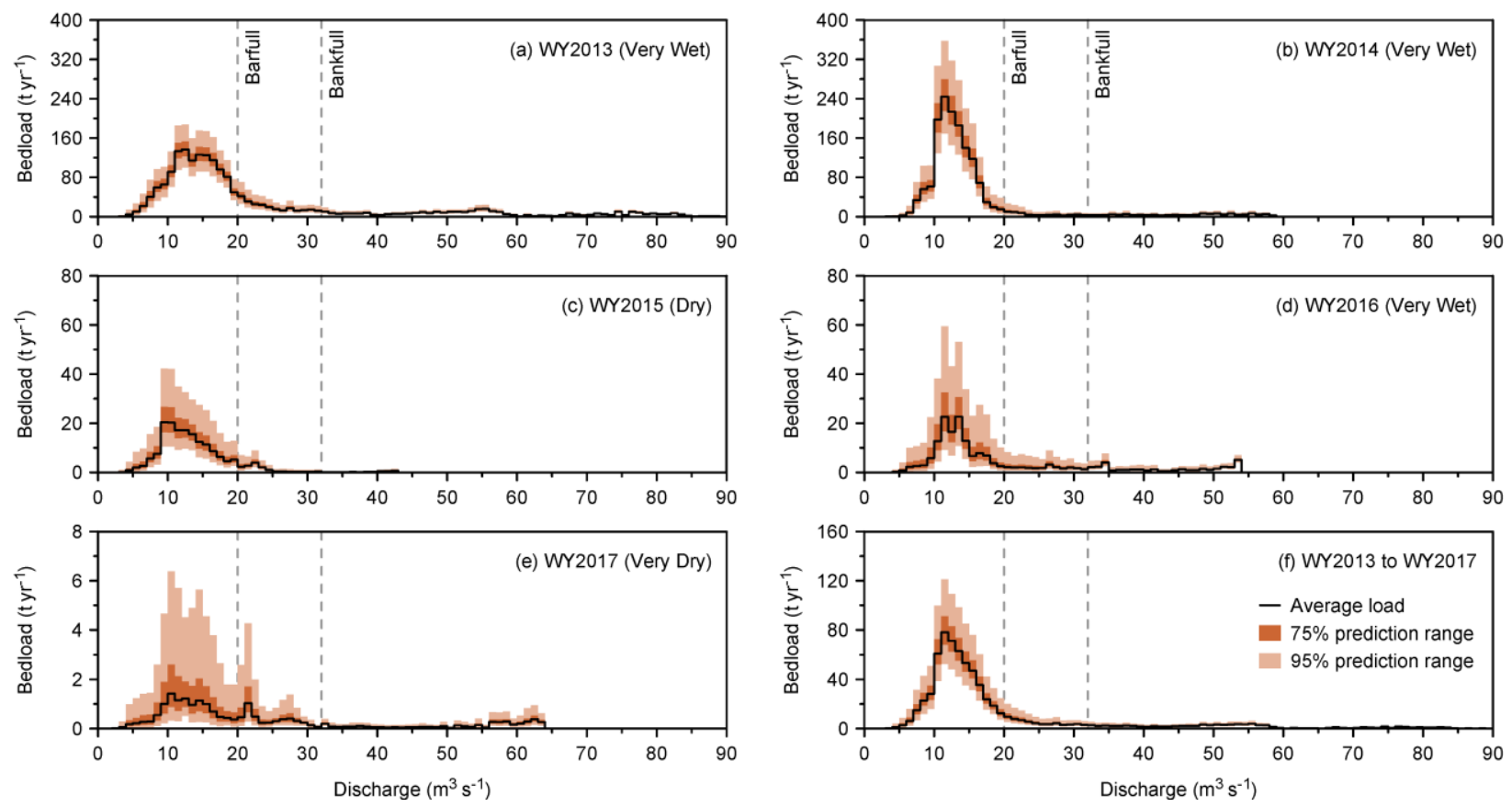

Figure 5: Magnitude-frequency analysis of predicted cross-section bedload at $1 \mathrm{~m}^{3} \mathrm{~s}^{-1}$ increments during (a-e) individual Water Years 2013-2017 and (f) during the entire monitoring period. $75 \%$ and 95\% prediction intervals provide context. Results are scaled up to accommodate for periods with data omissions. Note: highly variable scaling of y-axes according to wetness of flow year.

\section{Persistent dominance of bar-building flows}

Processing impact count data through the BLIP model indicates that annual yields of crosssectional coarse bedload vary by two-orders of magnitude between water years 2013 and 2017. Whereas the Very Dry WY2017 transported just below $20 \mathrm{t}$ of coarse sediment, the Very Wet years of 2013 and 2014 transported 1,853 and 1,571 t, respectively. Between these extremes, the Dry year of WY2015 transported $176 \mathrm{t}$, similar to WY2016 (188 t) which is classed as a Very Wet year but contains few high magnitude events. Despite these considerable differences, the relative distribution of bedload yield per unit discharge reveals remarkable similarity between 
years (Figure 5), with peak annual load occurring around one-third of the bankfull flow, $\mathrm{Q}_{\mathrm{bf}}$, (c. $11-12 \mathrm{~m}^{3} \mathrm{~s}^{-1}$ : range $\left.0.30-0.42 \mathrm{Qbf}\right)$ and the vast majority of coarse bedload conveyed by flows below the barfull reference level $\left(20 \mathrm{~m}^{3} \mathrm{~s}^{-1}, 0.62 \mathrm{Qbf}_{\mathrm{b}}\right)$.

The persistent dominance of the bar-building flows arises as a result of the high frequency of sub-barfull flows in the lower Avon capable of transporting coarse bedload, combined with the prevalence of negative hysteresis generating proportionally larger bedload yields during the waning flows of significant events (see Analysis). Whereas gravel beds typically remain largely inactive during in-bank flows, in the Avon the bulk of coarse bedload is mobilized during inbank flows, e.g., in WY2013, 71\% of the flow duration when the bed is active (above $8 \mathrm{~m}^{3} \mathrm{~s}^{-1}$ ) occurred below barfull $\left(20 \mathrm{~m}^{3} \mathrm{~s}^{-1}\right)$. Figure 6 reveals that the receding flows consistently account for two-thirds of the annual flow duration across the five water years, which is matched by twothirds of the annual coarse bedload yield. Thus, the high resolution data suggest that bedload 'yield' lags significantly with respect to peak flows irrespective of the wetness of the water year, and serves to corroborate earlier identification (Downs et al., 2016) of the primacy of negative hysteresis at the event scale in this river.

(a)

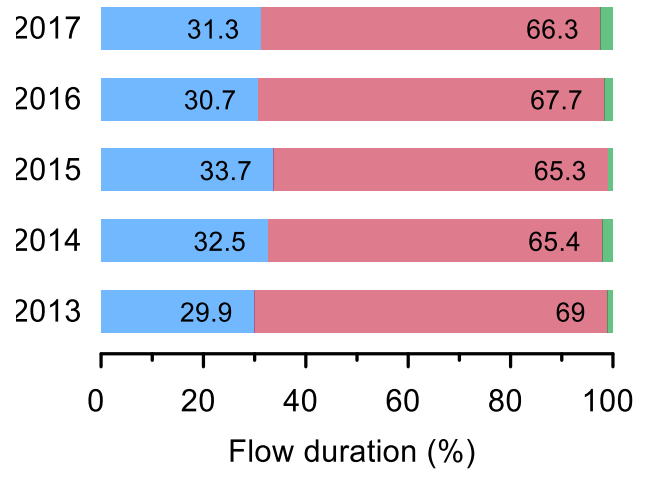

rising limb (b)

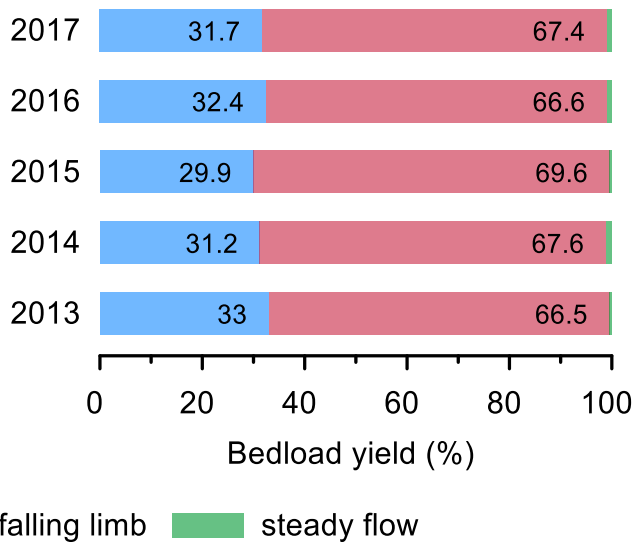

Figure 6: Comparison of (a) duration of rising and falling limbs and (b) subsequent estimates of related coarse bedload yield estimates for Water Years 2013-2017 in the lower River Avon.

\section{Analysis of coarse bedload dynamics}

Analysis of coarse bedload transport typically explores the relationship between capacity (usually expressed as a function of flow magnitude, shear stress or energy exceeding a critical threshold for particle entrainment) and instantaneous transport rate. Such sediment rating curves are prevalent in the literature on sediment transport dynamics and river channel management, with bedload-transport capacity providing a "benchmark against which the ability of a stream to transport sediment can be measured and compared" (Wainwright et al., 2015, p.1158). However, quite unlike the log-linear trend of conventional rating curves, the data scatter illustrated in Figure 4 clearly indicates that there is no simple, monotonically increasing and annually 
invariant relationship between instantaneous discharge and high-resolution coarse bedload measurements on the Devon Avon. Further, the persistent dominance, but varying peakedness, of bar-building flows as the most effective range of sediment-transporting discharges across multiple hydrological year types (Figure 5) implies that flow energetics are only partially responsible for rates and volumes of coarse sediment transport in the lower River Avon. Developing these themes, analyses below focus on the existence of a two-phase sediment rating curve that appears to reflect controls on coarse bedload other than direct energetic factors, and development of an index to account for the overall influence of flow history on coarse sediment transport.

\section{Evidence for a two-phase rating curve for coarse bedload}

Variability in the relationship between discharge and bedload transport rate can be partly accounted for in terms of hysteric and supply-limiting effects (Aigner et al., 2017; Gunsolus \& Binns, 2018; Reid et al., 1985; Mao, 2012; Moog and Whiting, 1998), phases or process-types of sediment transport (Kreisler et al., 2017; Ryan et al., 2002), sensitivity to sediment size (Hassan $\&$ Church, 2001) and variation in channel and floodplain morphology (Ryan et al., 2005). Here, annual and multi-annual sediment rating curves (Figure 7) developed using LOWESS curve fitting (Cleveland, 1979), and normalized to facilitate comparison, illustrate two distinct phases not otherwise described in the research literature and presumed to reflect insights permitted by the multi-annual high-resolution data.

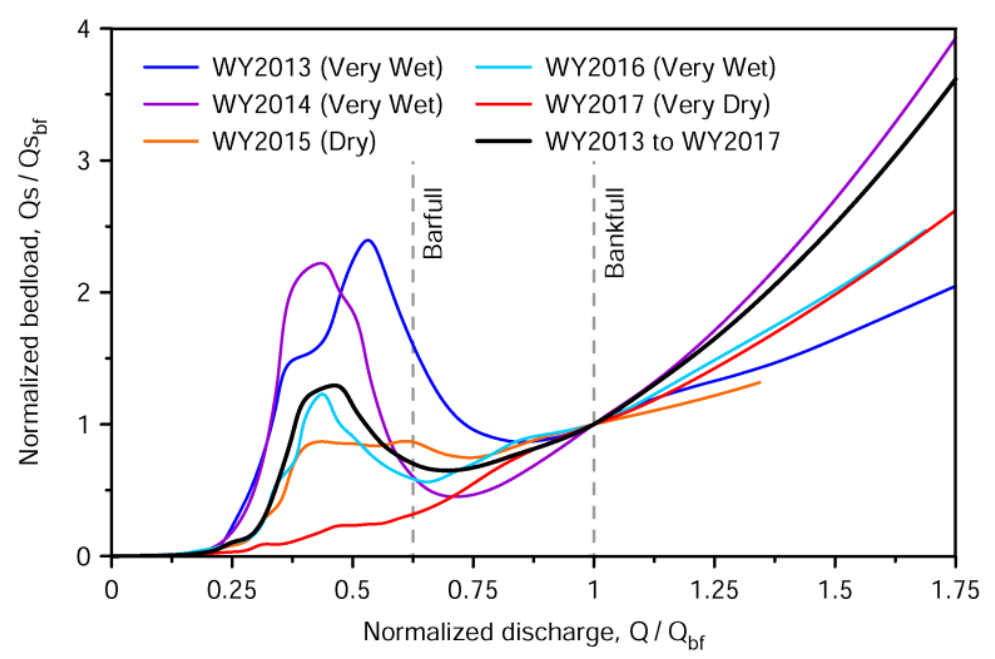

Figure 7: Annual and multi-annual relationships between instantaneous discharge and coarse bedload transport rate for the Devon Avon (WY2013-2017), normalized by discharge (Q) and unit bedload rate (Qs) at the bankfull condition $\left(\mathrm{Q}_{\mathrm{bf}}\right.$ and $\mathrm{Qs}_{\mathrm{bf}}$, respectively). The non-linear 'bulge' element in transport rates below $\approx 0.8 \mathrm{Q}_{\mathrm{bf}}$ varies from more than twice those at bankfull in Very Wet years to barely discernable during the Very Dry WY2017. Note: bedload rate is the geometric average of the BLIP Monte Carlo output distribution; relationships developed using LOWESS curve fitting (Cleveland, 1979). 
Figure 7 depicts a near-linear (or very gently curving) trend between discharge and sediment transport rates for flows that exceed $20-25 \mathrm{~m}^{3} \mathrm{~s}^{-1}\left(\approx 0.6-0.8 \mathrm{Qbf}_{\mathrm{bf}}\right.$, Figure 7$)$, whereas for flows below $\approx 0.8 \mathrm{Q}_{\text {bf }}\left(25 \mathrm{~m}^{3} \mathrm{~s}^{-1}\right)$, bedload rates prescribe a pronounced, non-linear and annuallyvariable 'bulge' in rates that precedes a variable trough between barfull and bankfull flows. However, these trends represent average rates and thus potentially mask the intricate dynamics and stochastic behavior inherent to bedload transport over the duration of individual events. To illustrate such complex behavior and provide a potential explanation for the bulge feature, Figure 8 tracks bedload transport rate as it varied with discharge during a large multi-peaked hydrograph in December 2012.

The two initial flood events (peaking at $58 \mathrm{~m}^{3} \mathrm{~s}^{-1}$ and $89 \mathrm{~m}^{3} \mathrm{~s}^{-1}$ ) portray positive hysteresis for the out-of-bank component, suggesting capacity-driven rising flows but with supply-limited transport as flooding recedes and flows retreat back into the channel (Figure 8a-d). Secondary bedload pulses are reflected in the negative hysteresis of the below-bankfull flows (Figure 8b, f), which appears to be a general characteristic of the lower Avon and analogous to observations of Reid et al. (1985). The effect is more notable following the initial peak and likely accentuated because impacts for the right-hand impact plate are both numerous and significantly lagged with respect to discharge (see Downs et al., 2016: Table 1, Figure 12): field observations suggest that the thalweg of waning high flows is deflected progressively towards the channel right bank, causing (finer) bedload to cross the right-hand plate late in flood events. The duration of the subbarfull flows following the peak flood events is reflected in the detailed fluctuation of bedload rate in Figures 8c, e and $\mathrm{f}$, which cumulatively contributes to the highly effective range of flows below $20 \mathrm{~m}^{3} \mathrm{~s}^{-1}$ in Figure 5a. The overall effectiveness of such sub-barfull events on event-scale sediment yield results in the dominance of negative hysteresis as reported previously (Downs et al., 2016) and summarized in Figure 6. The inconsistent transport rate with discharge also provides some evidence that the phenomenon is less likely to relate to systemic issues of impact plate detection and recording.

Following evidence from Figure 8 (and other events not illustrated), the upper phase in Figure 7 is interpreted as reflecting capacity-limited transport during rising flows, with coarse bedload transport rates driven by progressive increases in bed shear stresses during high in-bank and overbank flows, but with sediment availability limitations as overbank flows recede. The 5-year relationship (black line in Figure 7) is conditioned largely by the frequency of high flows during WY2014. A conventional log-linear rating curve for this upper phase applied to WY2013-2017 data unsurprisingly exhibits low explained variance $\left(\mathrm{R}^{2}=0.19\right)$, reflecting the inherent shortterm stochasticity between discharge and coarse bedload transport (inherent in Figures 4 and 5) and the imbalance between capacity-related rising flows and sediment-limited falling flows, that is, positive hysteresis for the out-of-bank flow component. Identification of these is permitted only as a function of near-continuous monitoring.

The lower phase in Figure 7 is interpreted as relating primarily to supply factor variations during in-bank flows which are evidently accentuated in the high flow WYs of 2013 and 2014. As 
such, they are likely to reflect, first, the coupling of sediment transport pulses during recurrent, moderately-sized, in-bank events whose frequency prevents the bed from consolidating effectively during the intervening low flow conditions. Second, they reflect sediment pulses allied to recession flows following high magnitude events (i.e., negative hysteresis) caused by the lagged delivery of coarse sediment from distal parts of the channel network during the longer-lasting high flows. Our results reveal the convexity of the bulge decreases in proportion with some combination of annual wetness and occurrence of large flows so that in the Very Dry WY of 2017 it barely exists (see next section).

Overall, the continuous data suggest that coarse sediment rating curves can reflect a combination of supply-related and capacity-related controls, varying by water year type, and provide empirical evidence for the argument that a solely capacity-related understanding of bedload transport is indeed insufficient (Pfeiffer et al., 2017; Wainwright et al., 2015).
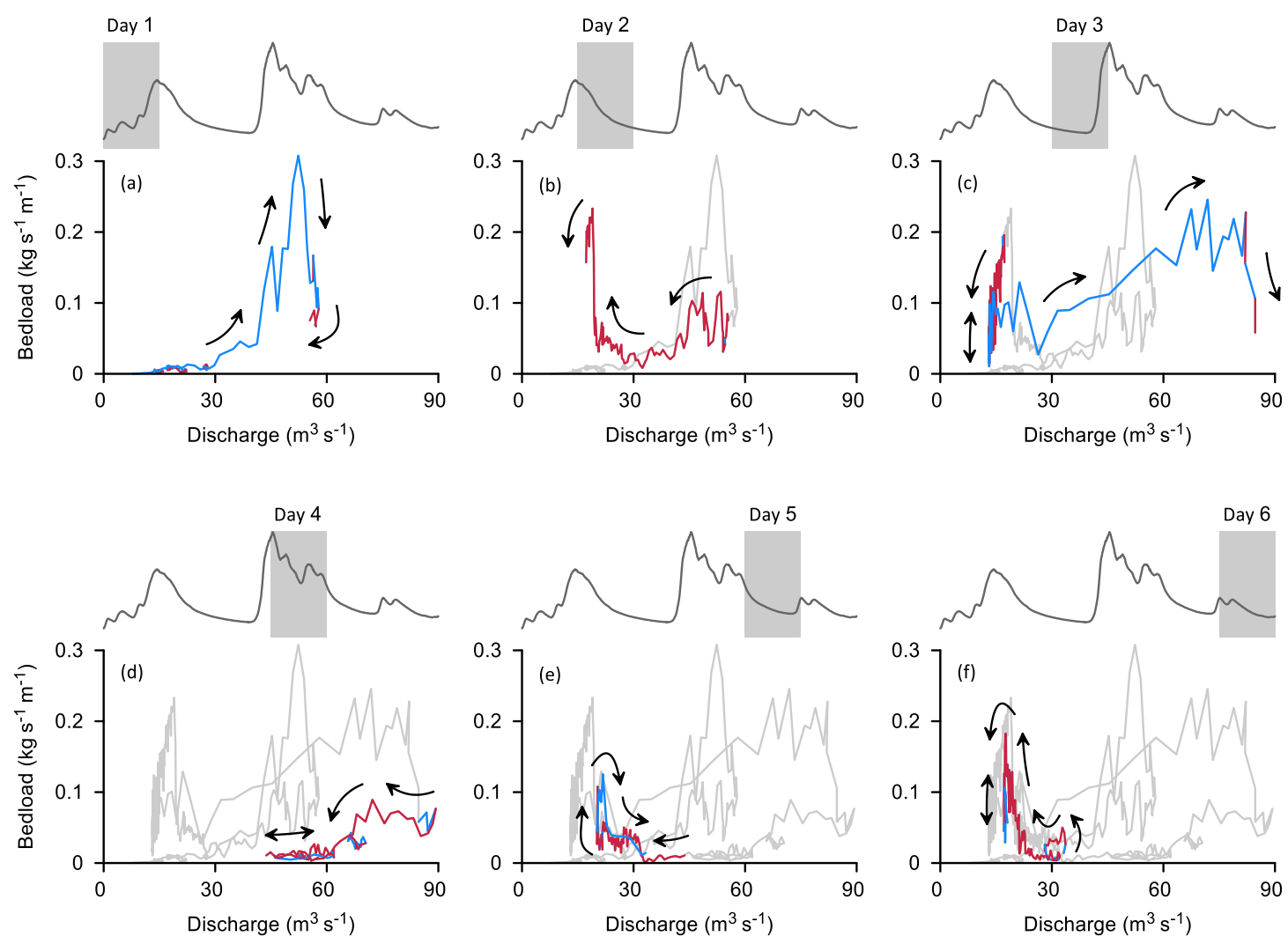

Figure 8: Depiction of hysteretic pathway of coarse bedload transport at 15-minute intervals for a large, multi-peaked 6-day flow event from $7 \mathrm{am}$ on $19^{\text {th }}$ December 2012. Individual panels represent one day of the storm period. The upper panel indicates flow discharge and the lower coarse bedload transport rate. Bedload during rising limb periods is indicated in blue and during falling limbs in red. Past periods are indicated in gray and build a complex hysteretic pattern over the flow period, but with the highest density of activity in sub-barfull flows - a microcosm of sediment transport for the river in general. 
501 Flow history controls on coarse sediment transport

502 Accepting that coarse bedload transport rates include a significant supply-related component 503 during the passage of a hydrograph when viewed in high resolution opens the prospect that,

504 when variable, supply factors may invalidate assumptions of inter-annual stationarity intrinsic to 505 bedload rating curves. Ideally, investigations would encapsulate annual variability in watershed506 scale sediment coupling, network-scale delivery mechanisms and reach-scale bed conditioning, as noted earlier, but this is rarely practicable. Flume-scale analogies are derived from calls for a metric of 'stress history' to explain inter-event differences in sediment mobility and availability (Hayes \& Pender, 2007; Mao, 2012; Monteith \& Pender, 2005; Ockelford \& Haynes, 2013). Such studies imply an analytical expression for the sediment supply component of bedload transport akin to classic conceptualizations of temporal controls on landform sensitivity (Brunsden \& Thornes, 1979), with factors expressing a summary of disturbance events (D) relative to an intervening relaxation period $(R)$.

Upscaling the stress history concept, and presuming that outside of headwater streams interannual variability in watershed-scale sediment coupling is partially buffered by network-scale sediment stores, $D$ can be expressed by the annual potential for delivery of particles into the monitored reach - a virtual velocity derived from the 'integrated excess transport capacity' present (variations on this theme in Downs et al., 2016; Rickenmann et al., 2012; Phillips et al., 2018). Following evidence that multiple moderate events can be responsible for greater particle travel distances than single higher-magnitude events (Papangelakis \& Hassan, 2016), and the loss of direct correlation between critical shear stress and sediment transport during high flows (Masteller et al., 2019), $D$ is conceivably related most closely to the annual duration of flows that exceed the lower limit of the range of effective discharges. The relaxation period $R$ expresses the annual extent of reach-scale antecedent 'preparation' - the period of near-threshold flows in which particles orientate themselves parallel to the flow and finer sediments are winnowed vertically, conditioning the bed to more effectively resist sediment entrainment. The relevant flows are thus those below the quasi-threshold of general entrainment but above base flows in which no sediment movement occurs, encapsulating 'vibration' flows in which particles re-pack and consolidate the bed structure (Haynes \& Pender, 2007; Mao, 2018; Masteller \& Finnegan, 2017, Ockelford \& Haynes, 2013; Ockelford et al., 2019).

The sediment supply metric should explain the supply-dependent component of the annual bedload yield, defined here by the relative magnitude of the 'bulges' in the instantaneous sediment transport rates illustrated in Figure 7. The bulges are parametrized as a 'supply-related bedload factor' defined as the ratio of the bedload rate at bulge peak ( $\left.\mathrm{Q}_{\mathrm{s} \text { peak }}\right)$ to that at the succeeding trough $\left(\mathrm{Q}_{\mathrm{s} \text { trough, }}\right.$ usually about $0.8 \mathrm{Q}_{\mathrm{bf}}$, ) beyond which transport rates are highly variable and appear to reflect both capacity and supply controls (Figure 8). A dimensionless form of the Sediment Supply metric $(S S)$ for coarse bedload transport can thus be envisaged as: 


$$
\boldsymbol{S S}=\frac{\text { Disturbing force }}{\text { Antecedent preparation }}=\frac{\boldsymbol{D}}{\boldsymbol{R}}=\frac{\text { Duration }_{>\text {critical }}}{\text { Volume }_{\text {conditioning }}}
$$

where $D$ is defined as the annual proportion of time $\left(\mathrm{T}^{*}\right)$ that flow exceeds the peak of the supply bulge (i.e., $\geq 11 \mathrm{~m}^{3} \mathrm{~s}^{-1}$ ), and $R$ is defined as the annual proportion of the duration-magnitude product (i.e., flow volume, $\mathrm{V}^{*}$ ) from the point of rapidly increasing coarse bedload activity (here, $8 \mathrm{~m}^{3} \mathrm{~s}^{-1}$, Figures 4, 5) down to the absolute lower threshold entrainment of coarse bedload (here, $3 \mathrm{~m}^{3} \mathrm{~s}^{-1}$, Downs et al., 2016, their Figure 9). The choice of thresholds for $D$ and $R$ will be river, location and instrument dependent.

Expressing $S S$ in this way provides a remarkably strong explanation (Figure $\mathbf{9}, \mathrm{R}^{2}=0.985$ ) of the scale of the supply bulge from conditions of negligible bulge (WY2017) to those with an exceptional relative magnitude of supply-related bedload transport (WY2014). Flow years are aligned from driest to wettest with greatest proportions of supply-related transport in the wetter years. Relationships were poorer when $R$ was defined as a duration rather than a volume of flows 3-8 $\mathrm{m}^{3} \mathrm{~s}^{-1}$, and far poorer when annual bulges were related to data from the previous year's flow regime. The former is interpreted to suggest that the duration-magnitude product is superior to duration alone because flows closer to $8 \mathrm{~m}^{3} \mathrm{~s}^{-1}$ are proportionately more effective at repacking the channel bed; the latter that instantaneous transport rates are little impacted by flows from the previous water year (for yields, see below). There is, therefore, field evidence for an analytical descriptor of the supply-related component of instantaneous coarse bedload measurements revealed through high resolution, long-term monitoring over multiple years.

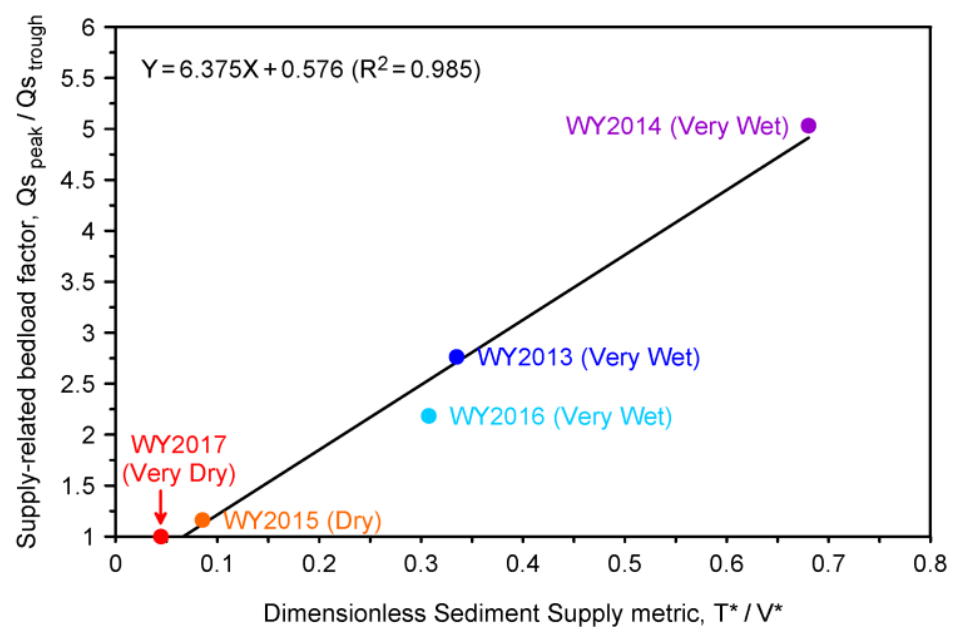

Figure 9: Relative magnitude of the supply-related bedload factor ( $Q s_{\text {peak }} / \mathrm{Qs}$ trough $)$ related to a dimensionless Sediment Supply metric defined as the ratio of disturbance $(D)$ to antecedent preparation $(R)$, represented by the ratio of the proportional duration $\left(\mathrm{T}^{*}\right)$ of flows exceeding $11 \mathrm{~m}^{3} \mathrm{~s}^{-1}$ to the proportion of the combined volume $\left(\mathrm{V}^{*}\right)$ of flows in the range $3-8 \mathrm{~m}^{3} \mathrm{~s}^{-1}$. 
561 Analysis was extended to examine whether the Sediment Supply metric could provide insight 562 regarding the fraction of the annual yield of coarse bedload $\left(\mathrm{L}^{*}\right)$ contributed by the low flows not 563 exceeding the effective discharge (i.e., below $11 \mathrm{~m}^{3} \mathrm{~s}^{-1}$, about one-third of bankfull flow, Figure

564 5). Using current year flows there is almost no relation (Figure 10a) but $S S$ provides an 565 exceptional fit when related to the previous year of flows $\left(R^{2}=0.991\right.$, Figure 10b $)$, with the 566 sequence of flow years logically re-organized from those in Figure 9 to emphasize the relative 567 wetness of the prior year. For instance, the Dry water year of 2015, characterized by a greatest 568 proportion of sub- $11 \mathrm{~m}^{3} \mathrm{~s}^{-1}$ coarse sediment yield (34\%), has the strongest association with the SS 569 metric from the previous year, implying that the Very Wet WY2014 provided a relatively 570 abundant supply of coarse bedload for transport in WY2015, despite limited high flows. There 571 are also relatively elevated loads of 'moderate flow supplied' bedload in Very Dry year WY2017 572 following the Very Wet year WY2016. Conversely, the sub- $11 \mathrm{~m}^{3} \mathrm{~s}^{-1}$ component of the total 573 bedload yield was proportionately very low $(\sim 16 \%)$ in the Very Wet WY2016 that followed the 574 Dry WY2015, suggesting that prior catchment- and or network-scale sediment delivery into the reach was relatively low, and for the Very Wet WY2013 that followed an Average WY2012.

576 When two Very Wet years follow each other (e.g., WY2014 after WY2013) the effect is 577 apparently mediated by the absolute volume of material in transport. The results reinforce the 578 importance of the site's hysteretic condition (Figures 6, 8), where in drier years with few 579 overbank flows a larger proportion of sediment is transported on the rising limb of hydrographs, accentuating the importance of material import and/or bed looseness conditioned by the previous 581 year's flows. Such influence did not extent to the flows two years previously, which showed 582 only a poor correlation. 

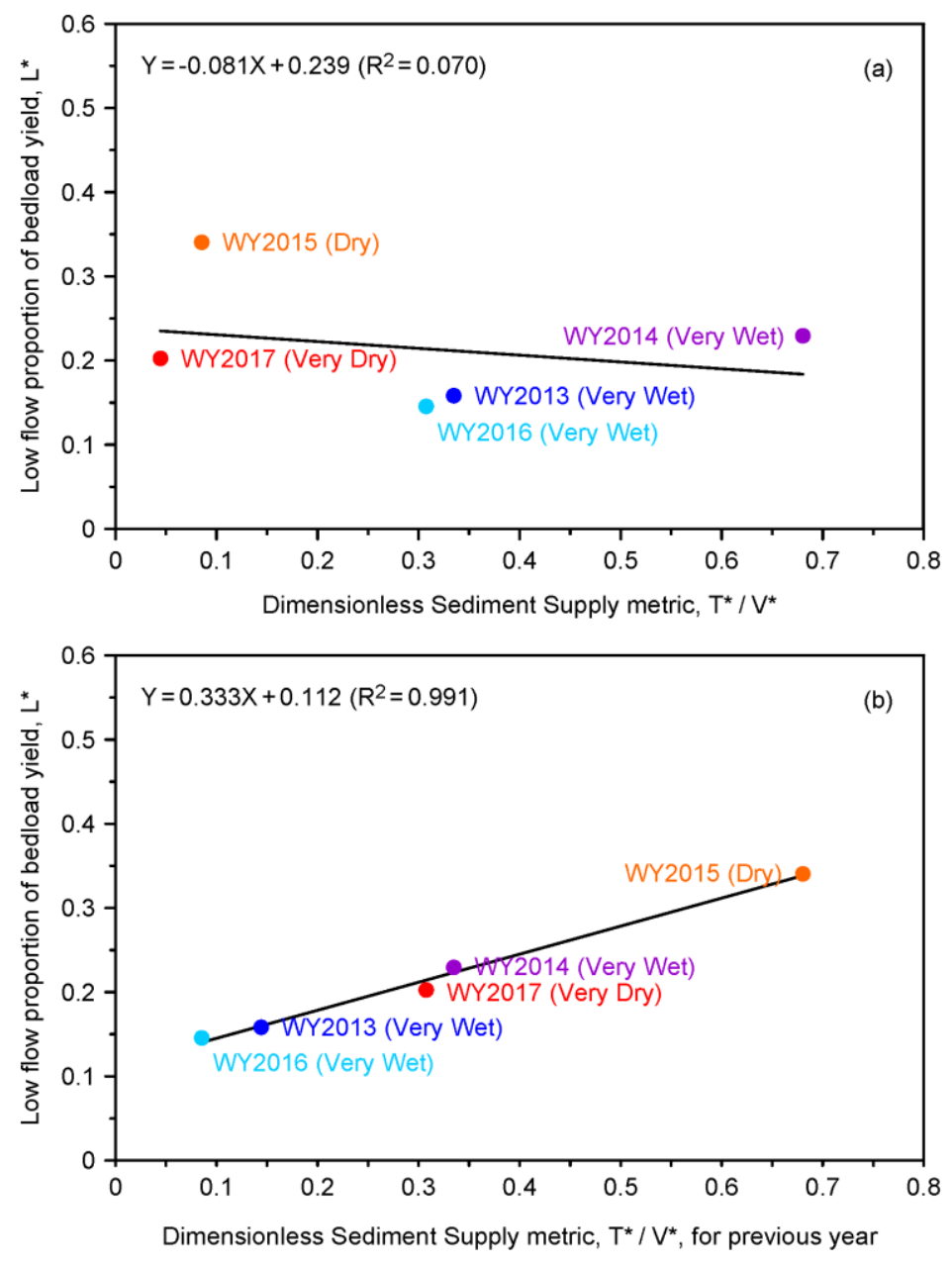

Figure 10: Best fit relation resulting from exploratory analysis to explain the relative proportion of total annual yields $\left(\mathrm{L}^{*}\right)$ of coarse bedload transported during 'low flows' $\left(<11 \mathrm{~m}^{3} \mathrm{~s}^{-1}\right)$ versus the Sediment Supply metric (see Figure 9) for (a) the current year of flows, and (b) for the previous year.

In summary, a sediment supply ratio describing the duration of effective bedload transporting flow and the volume of conditioning 'vibration' flows has provided field-scale insight into the geomorphological effectiveness of sub-barfull discharges on annual bedload and the importance of antecedent flow years in conditioning bedload availability for transport the following year. Insights are facilitated by continuous bedload monitoring but should be treated as indicative until wider analysis and testing is performed. Further, and critically, these results are particular to the hydrogeoclimatic context of our study site.

\section{Discussion and Prospect: beyond stationarity}

596 The recent emergence of multi-year, high resolution datasets for river bedload (Aigner et al., 597 2017; Masteller et al., 2019; Rickenmann, 2018) represents an initial realization of the predicted 598 'revolutionary' potential offered by passive bedload monitoring (Gray et al., 2010b), and marks a 
technological development that offers parity with advances already achieved by passive monitoring of other fluvial data parameters (e.g., flows using ADCPs, suspended sediment loads using OBS sensors, etc.). One inherent corollary of such developments, emphasized here by data-driven estimates of bedload yield, is a greater focus on time-dependencies in bedload transport than has hitherto been the case. Here, five years of data encompassing Very Dry to Very Wet water years emphasizes the non-linearity inherent to bedload transport even in the temperate humid setting of SW England; while annual flow volume varied by less than a factor of two (95.3-160.5 $\mathrm{M} \mathrm{m}^{3}$ ), annual coarse bedload estimates varied by two orders of magnitude $(\approx 20-2,000 \mathrm{t})$ and have wide prediction intervals. This attribute conceivably represents simple energetics, with transport ascending with event-scale flow volume, so subsuming the influence of short-term stochasticity, as demonstrated previously by Rickenmann et al. (2012) and Downs et al. (2016). Such 'integrated excess transport capacity' is argued to influence cumulative bedload flux irrespective of hydrograph size and shape in unimodal beds (Phillips et al., 2018). However, bedload yield is apparently also elevated in the wetter years by the frequency and duration of high in-bank and overbank flow events in combination with reduced consolidation and armoring of the channel bed during the near-critical 'vibrating' flows, that in combination lowers critical shear stress thresholds for entrainment (Masteller \& Finnegan, 2017; Monteith \& Pender 2005; Reid et al., 1985; Turowski et al., 2011) and facilitates sediment delivery from upstream.

\section{High-resolution recording in this river has produced two striking observations: 1) the persistent} primacy of sub-barfull flows as the range of flow that transports the majority of these variable loads (Figure 5), and; 2) the existence of two-phase annual sediment rating curves (Figure 7). The former demonstrates that high-resolution data provide detail on how non-linearly variable loads are achieved: in this case emphasizing both the competency of frequently occurring subbankfull flows (in this setting) and the overall negative hysteresis (Figure 6). The pronounced effectiveness of the sub-bankfull discharges relative to the bankfull condition is well documented in sand bed rivers (Sholtes \& Bledsoe, 2016; Soar \& Thorne, 2011) and in some gravel bed rivers where they may result in multiple formative discharges (Dollar, 2002; Lenzi, et al., 2006; Surian et al., 2009). In the lower River Avon, particularly during Very Wet years, the dynamics of coarse bedload transport are akin to flashy sand bed channels or ephemeral channels with characteristically weak armor layer development (see Powell et al., 2001). This facilitates the existence of significant sediment pulses both as flows rise and as they fall (e.g., Reid et al., 1985) but in this case the waning limb pulse following overtopping events is consistently of greater duration than the rising limb pulse, conceivably reflecting time-lagged delivery of sediment from upstream (Downs et al., 2016) that dominates yield at the event scale. Together, these pulses relegate the importance of the bankfull flow in its contribution to annual coarse sediment loads. Exceedance of critical shear stress far below bankfull stage is probably also indicative of high levels of sediment supply to the lower Avon, resulting in a channel morphology that is far from the low supply conditions of equilibrium 'threshold' channels, and conceivably also reflects existence of a 'deeper' bankfull channel (Pfeiffer et al., 2017). Both concepts appear consistent with field observations of abundant, labile, gravel bars, and river banks that display a sharp break 
639 from gravel-cobble basal sediments to a significant silt-loam upper layer that may have resulted 640 from deposition of tin mining wastes in the $15^{\text {th }}-16^{\text {th }}$ centuries AD (Thorndycraft, 2004). Such 641 behaviors would have been very difficult to observe using short-term active bedload monitoring.

642 Identification of two-phase sediment rating curves is likewise attributable to integrating high643 resolution data over annual and multi-annual timescales and can be interpreted as arising from 644 the predominance of coarse bedload (i.e., > $10 \mathrm{~mm}$ ) pulsing during sub-barfull flows. The 645 potential of a rating curve bulge is implied in all studies that have documented significant 646 hysteresis in bedload, especially where (as here) negative hysteresis dominates due to a 647 significantly time-lagged response in long duration high flows. That this attribute has not 648 previously been demonstrated reflects the value of long-term high-resolution monitoring in 649 faithfully representing the dynamics of bedload transport at this location, but also emphasizes 650 that higher resolution data likely benefit from locally-weighted curve-fitting techniques such as 651 LOWESS that do not default to a monotonic trend.

652 Associating the existence of time-dependent behaviors with changes in causality, including the 653 existence of supply-related factors, reflects calls to integrate a 'stress history' element into improving bedload estimates (Mao, 2012; Monteith \& Pender, 2005; Ockelford et al., 2019; Paphitis \& Collins, 2005), or to consider the onset of motion as a state-dependent property (Johnson, 2016; Masteller et al., 2019). Here, development of a sensitivity-style metric for sediment supply as an expression of disturbing forces to a relaxation period is used to explore the relative magnitude of supply-related controls on instantaneous and annual coarse bedload transport. Disturbing forces defined by the duration of flows exceeding a transport threshold describing the most effective flows expresses the ability of a reach to release bed material locally and import it from distance. The relaxation period involves antecedent preparation expressed as a duration-magnitude product of 'vibration' flows that consolidate and incrementally armor the channel bed, increasing the shear stresses required to entrain bed sediment. On annual timeframes, the results are ordered logically to indicate that the relative extent of supplyconditioned sediment is indeed a function maximizing the duration of disturbing events and minimizing the volume of bed consolidating flows (Figure 9); this emphasizes the role of supply factors in years that are continuously wet (i.e., WY2014) rather than those with large events (i.e., WY2013). However, the relative proportion of total supply-related bedload in any one water year is critically dependent on the relative wetness of the previous year, such that the proportional yield delivered by low flows is maximized during dry years that follow relatively wet years (Figure 10). Overall, there is evidence for the influence of network-scale supply factors, reach-scale stress conditioning of the bed morphology and a flow regime legacy from previous flow years. The data thus demonstrate a reach-scale upscaling of stress history perspectives achieved from laboratory studies.

Highlighted by high resolution, multi-year data, the apparent combination of capacity- and supply-related controls on coarse sediment transport suggest that bedload dynamics of a river 
and position in river basin which provide the temporal and spatial context for reach-scale stochasticity of bedload transport. The precise results obtained here will likely only be replicated in a catchment very similar to the Avon. Different combinations of supply-capacity control relationships should be expected elsewhere, for example, in headwater settings. More generally, continuous measurements suggest that coarse bedload transport is controlled by a multiplicity of factors that negate any general logic to support the pre-eminence of positive hysteresis over negative (or vice versa), or that particle arrangement matters more than upstream supply, and so on. Multi-year high resolution data demand time-dependent expressions of bedload transport that extend beyond stationarity and that encapsulate both capacity-related and supply-related controls to adequately describe bedload rates.

As hinted by early event-driven experiments in high-resolution data (notably Reid et al., 1985), continuous monitoring over extended time periods may fundamentally alter the way we view bedload, for instance (as here), in emphasizing the criticality of understanding sediment dynamics on the falling limb of hydrographs in addition to the rising limb which has been the overwhelming focus of most empirical studies. While passive monitoring instruments and techniques are by no means perfected, with challenges in instrument calibration and data processing techniques yet to be resolved, short time frame and/or coarse resolution monitoring of bedload provides only 'partial' perspectives on bedload transport and may have introduced significant data aliasing into interpretation to field results. The potential certainly exists for passive monitoring techniques to answer Wilcock's (2001) call for more practicable and accurate methods of bedload estimation and, in some regards, mainstreaming of passive bedload sensor records to improve and democratize bed sediment measurement would complete the move to 'big data' perspectives in fluvial system sciences. With suitable monitoring design strategies, passive monitoring can offer the basis for properly comprehending the impact of changing climate, land uses and river restoration on bedload transport and the maintenance, turnover, and recovery of bedform-dependent aquatic habitats. An opportunity exists to use passive monitoring to assemble bedload datasets particular to characteristic river 'types' and so enhance the knowledge base for restoring aquatic biodiversity and improving the sustainability of river management, as a contribution to a place-based analysis and management of river systems (Brierley et al., 2013).

\section{Acknowledgments}

Research was initially funded by a grant from the Seale-Hayne Education Trust to PWD. An exchange program grant from CONICYT Chile facilitated productive early discussion with Luca Mao and Ricardo Carrillo. The authors are indebted to Claire Masteller and three anonymous reviewers whose constructive comments greatly improved the manuscript. The impact plates were constructed by Ian Benson (iandesignandbuild@gmail.com). Richard Hartley is thanked for his field expertise and for modifying the impact plates to enable bankside data downloads. Tim Absalom and the University of Plymouth GeoMapping Unit are thanked for drafting Figure 
1. We are grateful to Adrian Simpson and John Hosking for permission to access their land. Gaging station data were provided by the Environment Agency. The authors declare no conflicts of interest. Data are available via the authors and https://sei.thedata.place/.

\section{References}

Aigner, J., Kreisler, A., Rindler, R., Hauer, C., \& Habersack, H. (2017). Bedload pulses in a hydropower affected alpine gravel bed river. Geomorphology, 291, 116-127. https://doi:10.1016/j.geomorph.2016.05.015

Andrews, E. D. (1980). Effective and bankfull discharges of streams in the Yampa river basin, Colorado and Wyoming. Journal of Hydrology, 46, 311-330. https://doi:10.1016/00221694(80)90084-0

Barrière, J., Krein, A., Oth, A., \& Schenkluhn, R. (2015). An advanced signal processing technique for deriving grain size information of bedload transport from impact plate vibration measurements. Earth Surface Processes and Landforms, 40, 913-924. https://doi:10.1002/esp.3693

Barry, J. J., Buffington, J. M., \& King, J. G. (2004). A general power equation for predicting bed load transport rates in gravel bed rivers. Water Resources Research, 40, W10401. https://doi:10.1029/2004wr003190

Beechie, T. J., Sear, D. A., Olden, J. D., Pess, G. R., Buffington, J. M., Moir, H., Roni, P., \& Pollock, M. M. (2010). Process-based principles for restoring river ecosystems. Bioscience, 60, 209-222. https://doi:10.1525/bio.2010.60.3.7

Boardman, J. (2013). The hydrological role of 'sunken lanes' with respect to sediment mobilization and delivery to watercourses with particular reference to West Sussex, southern England. Journal of Soils and Sediments, 13, 1636-1644. https://doi:10.1007/s11368-0130754-7

Booth, D. B., Leverich, G. T., Downs, P. W., Dusterhoff, S. R., \& Arraya, S. (2014). A method for a spatially explicit representation of sub-watershed sediment yield, southern California, USA. Environmental Management, 53, 968-984. https://doi:10.1007/s00267-014-0251-9

Borselli, L., Cassi, P., \& Torri, D. (2008). Prolegomena to sediment and flow connectivity in the landscape: a GIS and field numerical assessment. Catena, 75, 268-277. https://doi:10.1016/j.catena.2008.07.006

Bradley S. B. (1990). Characteristics of tin-streaming channels on Dartmoor, UK. Geoarchaeology, 5, 29-41. https://doi:10.1002/gea.3340050104

Bravo-Espinosa, M., Osterkamp, W. R., \& Lopes, V. L. (2003). Bedload transport in alluvial channels. Journal of Hydraulic Engineering, 129, 783-795. https://doi:10.1061/(asce)07339429(2003)129:10(783)

Brierley, G. J., Fryirs, K. A., Cullum, C., Tadaki, M., Huang, H. Q., \& Blue, B. (2013). Reading the landscape: integrating the theory and practice of geomorphology to develop place-based 
understandings of river systems. Progress in Physical Geography, 37, 601-621. https://doi:10.1177/0309133313490007

Brunsden, D., \& Thornes, J. B. (1979). Landscape sensitivity and change. Transactions of the Institute of British Geographers, NS4, 463-484.

Buffington, J. M., \& Montgomery, D. R. (1997). A systematic analysis of eight decades of incipient motion studies, with special reference to gravel-bedded rivers. Water Resources Research, 33, 1993-2029. https://doi:10.1029/96wr03190

Bunte, K., Abt, S. R., Potyondy, J. P., \& Ryan, S. E. (2004). Measurement of coarse gravel and cobble transport using a portable bedload trap. Journal of Hydraulic Engineering, 130, 879893. https://doi:10.1061/(ASCE)0733-9429(2004)130:9(879)

Cavalli, M., Trevisani, S., Comiti, F., \& Marchi, L. (2013). Geomorphometric assessment of spatial sediment connectivity in small Alpine catchments. Geomorphology, 188, 31-41. https://doi:10.1016/j.geomorph.2012.05.007

Church, M. (2010). Gravel-bed rivers. In Burt, T., Allison, R. (Eds.), Sediment cascades: An integrated approach (pp. 241-269). Chichester, UK: Wiley.

Cleveland, W. S. (1979). Robust locally weighted regression and smoothing scatterplots. Journal of the American Statistical Association, 74, 829-837. https://doi:10.1080/01621459.1979.10481038

Cui, Y., \& Wilcox, A. (2008). Development and application of numerical models of sediment transport associated with dam removal. In M. H. Garcia (Ed.), Sedimentation Engineering: Theory, Measurements, Modeling, and Practice, ASCE Manual (Vol. 110, pp. 995-1020). Reston, VA: American Society of Civil Engineers.

Dollar, E. S. J. (2002). Magnitude and frequency controlling fluvial sedimentary systems: issues, contributions and challenges. In F. J. Dyer, M. C. Thoms, J. M. Olley (Eds.), The structure, function and management implications of fluvial sedimentary systems, IAHR Publication (Vol. 276, pp. 355-362). Wallingford, UK: International Association for Hydro-Environment Engineering and Research.

Downs, P. W., \& Gregory, K. J. (2004). River channel management: Towards sustainable catchment hydrosystems. London: Arnold.

Downs, P. W., \& Piégay, H. (2019). Catchment-scale cumulative impact of human activities on river channels in the late Anthropocene: implications, limitations, prospect. Geomorphology, 338, 88-104. https://doi:10.1016/j.geomorph.2019.03.021

Downs, P. W., \& Soar, P. J. (2018). Determining the dynamics of coarse bedload transport using passive indirect monitoring: time-dependent variability at event to interannual scales. River Flow 2018 - Ninth International Conference on Fluvial Hydraulics, E3S Web of Conferences, 40, 05014. https://doi:10.1051/e3sconf/20184005014

Downs, P. W., Soar, P. J., \& Taylor, A. (2016). The anatomy of effective discharge: The dynamics of coarse sediment transport revealed using continuous bedload monitoring in a 
gravel-bed river during a very wet year. Earth Surface Processes and Landforms, 41, 147161. https://doi:10.1002/esp.3785

Elgueta-Astaburuaga, M. A., \& Hassan, M. A. (2017). Experiment on temporal variation of bed load transport in response to changes in sediment supply in streams. Water Resources Research, 53, 763-778. https://doi:10.1002/2016WR019460

Elgueta-Astaburuaga, M. A., \& Hassan, M. A. (2019). Sediment storage, partial transport, and the evolution of an experimental gravel bed under changing sediment supply regimes. Geomorphology, 330, 1-12. https://doi:10.1016/j.geomorph.2018.12.018

Elgueta-Astaburuaga, M. A., Hassan, M. A., Saletti, M., \& Clarke, G. K. C. (2018). The effect of episodic sediment supply on bedload variability and sediment mobility. Water Resources Research, 54, 6319-6335. https://doi:10.1029/2017WR022280

Emmett, W. W. (1975). The channels and waters of the Upper Salmon River area, Idaho, USGS Professional Paper, 870-A, 115 pp. Washington, DC: United States Geological Survey

Ferguson, R.I. (2005). Estimating critical stream power for bedload transport calculations in gravel-bed rivers. Geomorphology, 70, 33-41. doi:10.1016/j.geomorph.2005.03.009

Fryirs, K. (2013). (Dis)connectivity in catchment sediment cascades: a fresh look at the sediment delivery problem, Earth Surface Processes and Landforms, 38, 30-46. https://doi:10.1002/esp.3242

Fryirs, K. A., Brierley, G. J., Preston, N. J., \& Kasai, M. (2007). Buffers, barriers and blankets: the (dis)connectivity of catchment-scale sediment cascades. Catena, 70, 49-67. https://doi:10.1016/j.catena.2006.07.007

Gao, P. (2011). An equation for bedload transport capacities in gravel-bed rivers, Journal of Hydrology, 402, 297-305. https://doi:10.1016/j.jhydrol.2011.03.025

Garcia, C., Laronne, J. B., \& Sala, M. (2000). Continuous monitoring of bedload flux in a mountain gravel-bed river. Geomorphology, 34, 23-31. https://doi:10.1016/S0169555X(99)00128-2

Gomez, B. (2006). The potential rate of bed-load transport. Proceedings of the National Academy of Sciences, 103, 17170-17173. https://doi:10.1073/pnas.0608487103

Gomez, B., \& Church, M. (1989). An assessment of bed load sediment transport formulae for gravel bed rivers. Water Resources Research, 25, 1161-1186. https://doi:10.1029/wr025i006p01161

Goodess, C. M. (2013). How is the frequency, location and severity of extreme events likely to change up to 2060? Environmental Science and Policy, 27, S4-S14. https://doi:10.1016/j.envsci.2012.04.001

Gray, J. R. (2002). The need for surrogate technologies to monitor fluvial-sediment transport. Proceedings of the Federal Interagency Workshop on Turbidity and Other Sediment Surrogates Workshop, April 30-May 2, 2002, Reno, NV. http://water.usgs.gov/osw/techniques/turbidity.html 
Gray, J. R., Gartner, J. W., Barton, J. S., Gaskin, J., Pittman, S. A., \& Rennie, C.D. (2010a). Surrogate technologies for monitoring bed-load transport in rivers. In C. Poleto, S. Charlesworth (Eds.), Sedimentology of aqueous systems (pp. 46-79). Oxford: WileyBlackwell.

Gray, J. R., Laronne, J. B., Osterkamp, W. R., \& Vericat, D. (2010b). Bed load research international cooperative - BRIC. In J. R. Gray, J. B. Laronne, J. D. G. Marr (Eds.), Bedloadsurrogate monitoring technologies, USGS Scientific Investigations Report (Vol. 2010-5091, pp.208-217). Reston, VA: United States Geological Survey.

Gunsolus, E. H., \& Binns, A. D. (2018). Effect of morphologic and hydraulic factors on hysteresis of sediment transport rates in alluvial streams. River Research and Applications, 34, 183-192. https://doi:10.1016/S0169-555X(99)00128-2

Habersack, H. M., Nachtneb El, H. P., \& Laronne, J. B. (2001). The continuous measurement of bedload discharge in a large alpine gravel bed river. Journal of Hydraulic Research, 39, 125133. https://doi:10.1080/00221680109499813

Hall, J. W., Evans, E. P., Penning-Rowsell, E. C., Sayers, P. B., Thorne, C. R., \& Saul, A. J. (2003). Quantified scenarios analysis of drivers and impacts of changing flood risk in England and Wales: 2030-2100. Environmental Hazards, 5, 51-65. https://doi:10.1016/j.hazards.2004.04.002

Hassan, M. A., \& Church, M. (2001). Sensitivity of bed load transport in Harris Creek: Seasonal and spatial variation over a cobble-gravel bar. Water Resources Research, 37(3), 813-825. https://doi:10.1029/2000WR900346

Hassan, M. A., Egozi, R., \& Parker, G. (2006). Experiments on the effect of hydrograph characteristics on vertical grain sorting in gravel bed rivers. Water Resources Research, 42, W09408. https://doi:10.1029/2005WR004707

Haynes, H., \& Pender, G. (2007). Stress history effects on graded bed stability. Journal of Hydraulic Engineering, 133, 343-349. https://doi:10.1061/(ASCE)07339429(2007)133:4(343)

Hooey, T. (1992). Temporal variations in bedload transport rates and sediment storage in gravelbed rivers. Progress in Physical Geography, 16, 319-338. https://doi:10.1177/030913339201600303

Hooke, J. M. (2003). Coarse sediment connectivity in river channel systems: a conceptual framework and methodology. Geomorphology, 56, 79-94. https://doi:10.1016/S0169$555 \mathrm{X}(03) 00047-3$

Johnson, J. P. L. (2016). Gravel threshold of motion: a state function of sediment transport disequilibrium? Earth Surface Dynamics, 4, 685-703. https://doi:10.5194/esurf-4-685-2016

Kreisler, A., Moser, M., Aigner, J., Rindler, R., Tritthart, M., \& Habersack, H. (2017). Analysis and classification of bedload transport events with variable process characteristics. Geomorphology, 291, 57-68. https://doi:10.1080/00221680109499813 
Kuhnle, R. A., Wren, D. G., Hilldale, R. C., Goodwiller, B. T., \& Carpenter, W. O. (2017). Laboratory calibration of impact plates for measuring gravel bed load size and mass. Journal of Hydraulic Engineering, 143, 06017023. https://doi:10.1061/(ASCE)HY.19437900.0001391

Lamb, M. P., Dietrich, W. E. \& Venditti, J. G. (2008) Is the critical Shields stress for incipient sediment motion dependent on channel-bed slope? Journal of Geophysical Research: Earth Surface, 113, F02008. https://doi:10.1029/2007JF000831

Lenzi, M. A., Mao, L., \& Comiti, F. (2006). Effective discharge for sediment transport in a mountain river: computational approaches and geomorphic effectiveness. Journal of Hydrology, 326, 257-276. https://doi10.1016/j.jhydrol.2005.10.031

Mao, L. (2012). The effect of hydrographs on bed load transport and bed sediment spatial arrangement. Journal of Geophysical Research: Earth Surface, 117, F03024. https://doi:10.1029/2012JF002428

Mao, L. (2018). The effects of flood history on sediment transport in gravel-bed rivers. Geomorphology, 322, 196-205. https://doi:10.1016/j.geomorph.2018.08.046

Masteller, C. C., \& Finnegan, N. J. (2017). Interplay between grain protrusion and sediment entrainment in an experimental flume. Journal of Geophysical Research: Earth Surface, 122, 274-289. https://doi:10.1002/2016JF003943

Masteller, C. C., Finnegan, N. J., Turowski, J. M., Yager, E. M., \& Rickenmann, D. (2019). History-dependent threshold for motion revealed by continuous bedload transport measurements in a steep mountain stream. Geophysical Research Letters, 46, 2583-2591. https://doi:10.1029/2018GL081325

MEA (Millennium Ecosystem Assessment) (2005). Ecosystems and human well-being: Synthesis. Washington DC: Island Press, $137 \mathrm{pp.}$

Monteith, H., \& Pender, G. (2005). Flume investigation into the influence of shear stress history. Water Resources Research, 41, W12401. https://doi:10.1029/2005WR004297

Montgomery, D. R. (1999). Process domains and the river continuum. Journal of the American Water Resources Association, 35, 397-410. https://doi:10.1111/j.1752-1688.1999.tb03598.x

Moog, D. B., \& Whiting, P. J. (1998). Annual hysteresis in bed load rating curves. Water Resources Research, 34, 2393-2399. https:// https://doi.org/10.1029/98WR01658

Mueller, E.R., Pitlick, J., \& Nelson, J.M. (2005). Variation in the reference shields stress for bed load transport in gravel-bed streams and rivers. Water Resources Research, 41, W04006. doi:10.1029/2004wr003692

Nicholas, A. P., Ashworth, P. J., Kirkby, M. J., Macklin, M. G., \& Murray, T. (1995). Sediment slugs: large scale fluctuations in fluvial sediment transport rates and storage volumes. Progress in Physical Geography, 19, 500-519. https://doi:10.1177/2F030913339501900404

Null, S. E., \& Viers, J. H. (2013). In bad waters: Water year classification in nonstationary climates, Water Resources Research, 49, 1137-1148. https://doi:10.1002/wrcr.20097 
Ockelford, A.-M., \& Haynes, H. (2013). The impact of stress history on bed structure. Earth Surface Processes and Landforms, 38, 717-727. https://doi:10.1002/esp.3348

Ockelford, A.-M., Woodcock, S., \& Haynes, H. (2019). The impact of inter-flood duration on non-cohesive sediment bed stability. Earth Surface Processes and Landform. https://doi:10.1002/esp.4713

Papangelakis, E., \& Hassan, M.A. (2016). The role of channel morphology on the mobility and dispersion of bed sediment in a small gravelbed stream. Earth Surface Processes and Landforms, 41, 2191-2206. https://doi:/10.1002/esp.3980

Paphitis, D. \& Collins, M.B. (2005). Sand grain threshold, in relation to bed 'stress history': an experimental study. Sedimentology, 52, 827-838. https://doi: 10.1111/j.13653091.2005.00710.x

Pfeiffer, A. M., Finnegan, N. J., \& Willenbring, J. K. (2017). Sediment supply controls equilibrium channel geometry in gravel rivers. Proceedings of the National Academy of Sciences, 114, 3346-3351. https://doi:10.1073/pnas.1612907114

Phillips, C. B., Hill, K. M., Paola, C., Singer, M. B., \& Jerolmack, D. J. (2018). Effect of flood hydrograph duration, magnitude, and shape on bed load transport dynamics. Geophysical Research Letters, 45, 8264-8271. https://doi.org/10.1029/2018GL078976

Powell, D. M., Reid, I., \& Laronne, J. B. (2001). Evolution of bed load grain size distribution with increasing flow strength and the effect of flow duration on the caliber of bed load sediment yield in ephemeral gravel bed rivers. Water Resources Research, 37, 1463-1474. https://doi:10.1029/2000WR900342

Reid I., Frostick L. E., \& Layman J. T. (1985). The incidence and nature of bedload transport during flood flows in coarse-grained alluvial channels. Earth Surface Processes and Landforms, 10, 33-44. https://doi:10.1002/esp.3290100107

Richardson, K., Benson, I., \& Carling, P. A. (2003). An instrument to record sediment movement in bedrock channels. In J. Bogen, T. Fergus, D. E. Walling (Eds.), Erosion and sediment transport measurement in rivers: Technological and methodological advances, IAHS Publication (Vol. 283, pp. 228-235). Wallingford, UK: International Association of Hydrological Sciences.

Rickenmann, D. (2017). Bedload transport measurements with geophones, hydrophones, and underwater microphones (passive acoustic methods). In D. Tsutsumi, J. B. Laronne (Eds.), Gravel bed rivers: Processes and disasters (pp.185-208), Chichester, UK: Wiley.

Rickenmann, D. (2018). Variability of bed load transport during six summers of continuous measurements in two Austrian mountain streams (Fischbach and Ruetz). Water Resources Research, 54, 107-131. https://doi:10.1002/2017WR021376

Rickenmann, D. (2020). Effect of sediment supply on cyclic fluctuations of the disequilibrium ratio and threshold transport discharge, inferred from bedload transport measurements over 27 
years at the Swiss Erlenbach stream. Water Resources Research, 56, e2020WR027741. https://doi.org/10.1029/2020WR027741

Rickenmann, D., Turowski, J. M., Fritschi, B., Klaiber, A., \& Ludwig, A. (2012). Bedload transport measurements at the Erlenbach stream with geophones and automated basket samplers. Earth Surface Processes and Landforms, 37, 1000-1011. https://doi:10.1002/esp.3225

Roni, P., \& Beechie, T. (Eds.) (2013). Stream and watershed restoration: A guide to restoring riverine processes and habitats. Chichester, UK: Wiley.

Rosburg, T. T., Nelson, P. A., \& Bledsoe, B. P. (2017). Effects of urbanization on flow duration and stream flashiness: a case study of Puget Sound streams, Western Washington, USA.

Journal of the American Water Resources Association, 53, 1-15. https://doi:10.1111/17521688.12511

Ryan, S. E., Porth, L. S., \& Troendle, C. A. (2002). Defining phases of bedload transport using piecewise regression. Earth Surface Processes and Landforms, 27, 971-990. https://doi:10.1002/esp.387

Ryan, S. E., Porth, L. S., \& Troendle, C. A. (2005). Coarse sediment transport in mountain streams in Colorado and Wyoming, USA. Earth Surface Processes and Landforms, 30, 269288. https://doi:10.1002/esp.1128

Schumm, S. A. (1991) To Interpret the Earth: ten ways to be wrong. Cambridge: Cambridge University Press.

Sholtes, J. S., \& Bledsoe, B. P. (2016). Half-yield discharge: Process-based predictor of bankfull discharge. Journal of Hydraulic Engineering, 142, 04016017. https://doi:10.1061/(ASCE)HY.1943-7900.0001137

Soar, P. J., \& Downs, P. W. (2017). Estimating bedload transport rates in a gravel-bed river using seismic impact plates: model development and application. Environmental Modelling and Software, 90, 182-200. https://doi:10.1016/j.envsoft.2017.01.012

Soar, P. J., \& Thorne, C. R. (2011). Design discharge for river restoration. In A. Simon, S. J. Bennett, J. Castro (Eds.), Stream restoration in dynamic fluvial systems: Scientific approaches, analyses, and tools, AGU Geophysical Monograph (Vol. 194, pp. 123-149). Washington, DC: American Geophysical Union.

Surian, N., Mao, L., Giacomin, M., \& Ziliani, L. (2009). Morphological effects of different channel-forming discharges in a gravel-bed river. Earth Surface Processes and Landforms, 34, 1093-1107. https://doi:10.1002/esp.1798

Thorndycraft, V. R., Pirrie, D., \& Brown, A. G. (2004). Alluvial records of medieval and prehistoric tin mining on Dartmoor, southwest England. Geoarchaeology, 19, 219-236. https://doi:10.1002/gea.10114 
Twohig, S. (2014). Assessing coarse sediment connectivity of the River Avon, Devon: A geomorphological conceptual model based on physical catchment characteristics. Unpublished MRes Dissertation. Plymouth University, Plymouth, UK

Turowski, J. M., Badoux, A., \& Rickenmann, D. (2011). Start and end of bedload transport in gravel-bed streams. Geophysical Research Letters, 38. L04401. https://doi:10.1029/2010GL046558

Vericat, D., \& Batalla, R. J. (2010). Sediment transport from continuous monitoring in a perennial Mediterranean stream. Catena, 82, 77-86. https://doi:10.1016/j.catena.2010.05.003

Vogel, R.M., \& Fennessey, N. M. (1994). Flow-duration curves. I: new interpretation and confidence intervals. Journal of Water Resources Planning and Management, 120, 485-504. https://doi:10.1061/(ASCE)0733-9496(1994)120:4(485)

Wainwright, J., Parson, A. J., Cooper, J. R., Gao, P., Gillies, J. A., Mao, L., Orford, J. D., \& Knight, P. G. (2015). The concept of transport capacity in geomorphology. Reviews of Geophysics, 53, 1155-1202. https://doi:10.1002/2014RG000474

Wilcock, P. R. (2001). Toward a practical method for estimating sediment-transport rates in gravel-bed rivers. Earth Surface Processes and Landforms, 26, 1395-1408. https://doi:10.1002/esp.301

Wilcock, P. R., \& Crowe, J. C. (2003). Surface-based transport model for mixed-size sediment. Journal of Hydraulic Engineering, 129, 120-128. https://doi:10.1061/(ASCE)07339429(2003)129:2(120)

Wohl, E., Angermeier, P. L., Bledsoe, B., Kondolf, G. M., MacDonnell, L., Merritt, D. M., Palmer, M. A., Poff, N. L., \& Tarboton, D. (2005). River restoration. Water Resources Research, 41, W10301. https://doi:10.1029/2005WR003985

Wohl, E., Bledsoe, B. P., Jacobson, R. B., Leroy Poff, N., Rathburn, S. L., Walters D. M., \& Wilcox, A. C. (2015). The natural sediment regime in rivers: broadening the foundation for ecosystem management, Bioscience, 65, 358-371. https://doi:10.1093/biosci/biv002

Wolman, M. G. (1954). A method of sampling coarse river-bed material. Transactions, American Geophysical Union, 35, 951-956. https://doi:10.1029/tr035i006p00951

WWF (World Wildlife Fund) (2016). Living planet report 2016: Risk and resilience in a new era. Gland, Switzerland: WWF International.

Wyss, C. R., Rickenmann, D., Fritschi, B., Turowski, J. M., Weitbrecht, V., \& Boes, R. M. (2016a). Measuring bed load transport rates by grain-size fraction using the Swiss plate geophone signal at the Erlenbach. Journal of Hydraulic Engineering, 142, 04016003. https://doi:10.1061/(asce)hy.1943-7900.0001090

Wyss, C. R., Rickenmann, D., Fritschi, B., Turowski, J. M., Weitbrecht, V., \& Boes, R. M. (2016b). Laboratory flume experiments with the Swiss plate geophone bed load monitoring system: 1. Impulse counts and particle size identification. Water Resources Research, 52, 7744-7759. https://doi:10.1002/2015wr018555 
1017 Wyss, C. R., Rickenmann, D., Fritschi, B., Turowski, J. M., Weitbrecht, V., Travaglini, E., 1018 Bardou, E., \& Boes, R. M. (2016c). Laboratory flume experiments with the Swiss plate 1019 geophone bed load monitoring system: 2. Application to field sites with direct bed load 1020 samples. Water Resources Research, 52, 7760-7778. https://doi:10.1002/2016wr019283

1021 Yin, J., Gentine, P., Zhou, S., Sullivan, S.C., Wang, R., Zhang, Y. \& Guo S. (2018). Large 1022 increase in global storm runoff extremes driven by climate and anthropogenic changes.

1023 Nature Communications, 9, 4389, https://doi:10.1038/s41467-018-06765-2 
Figure 1. 


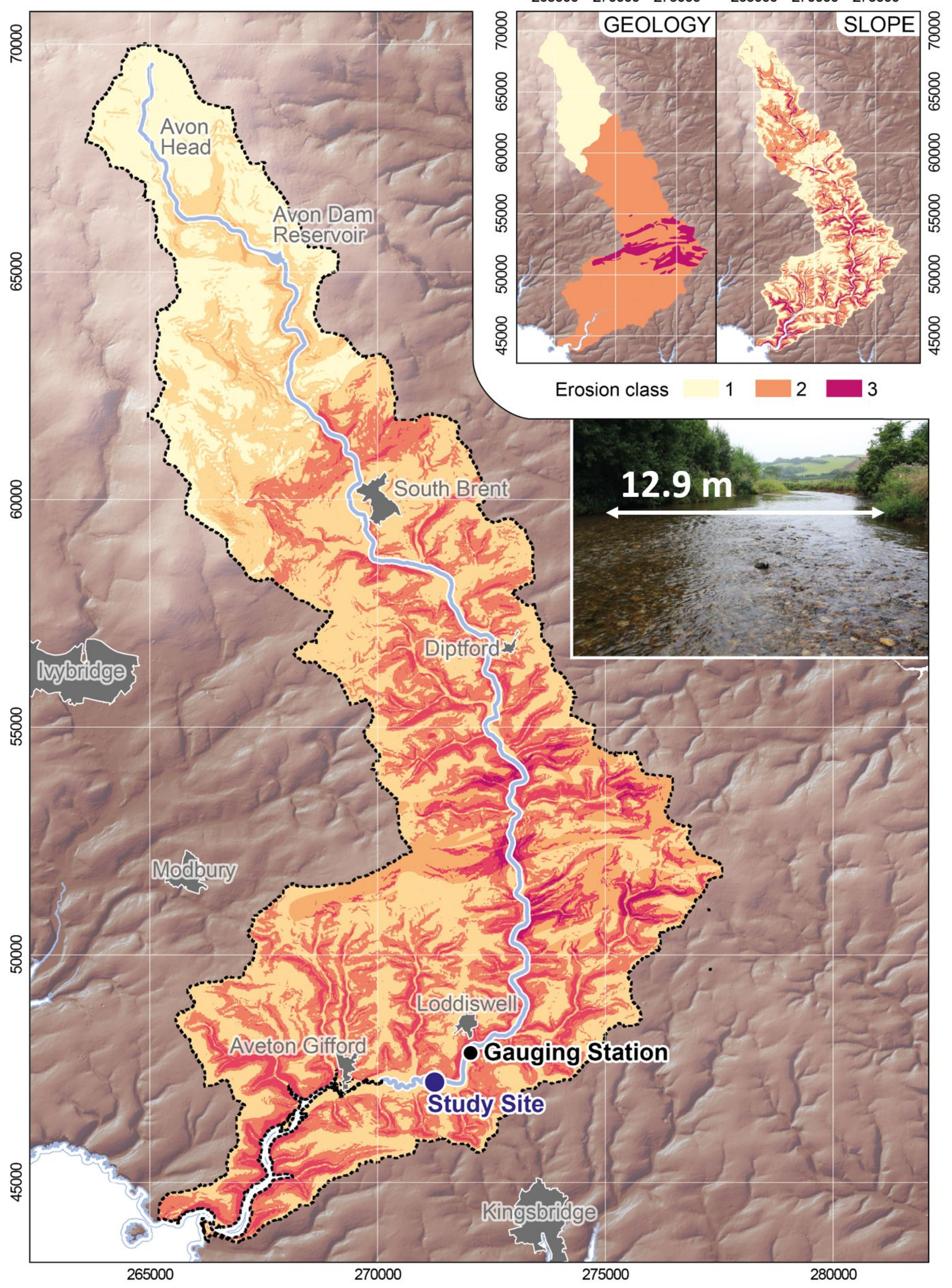

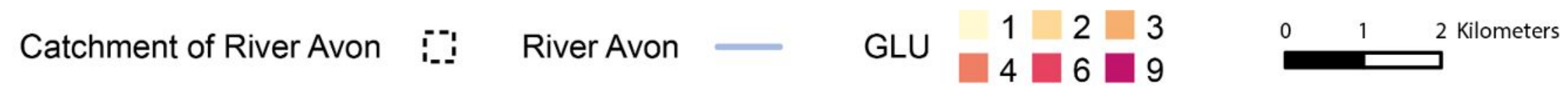


Figure 2. 


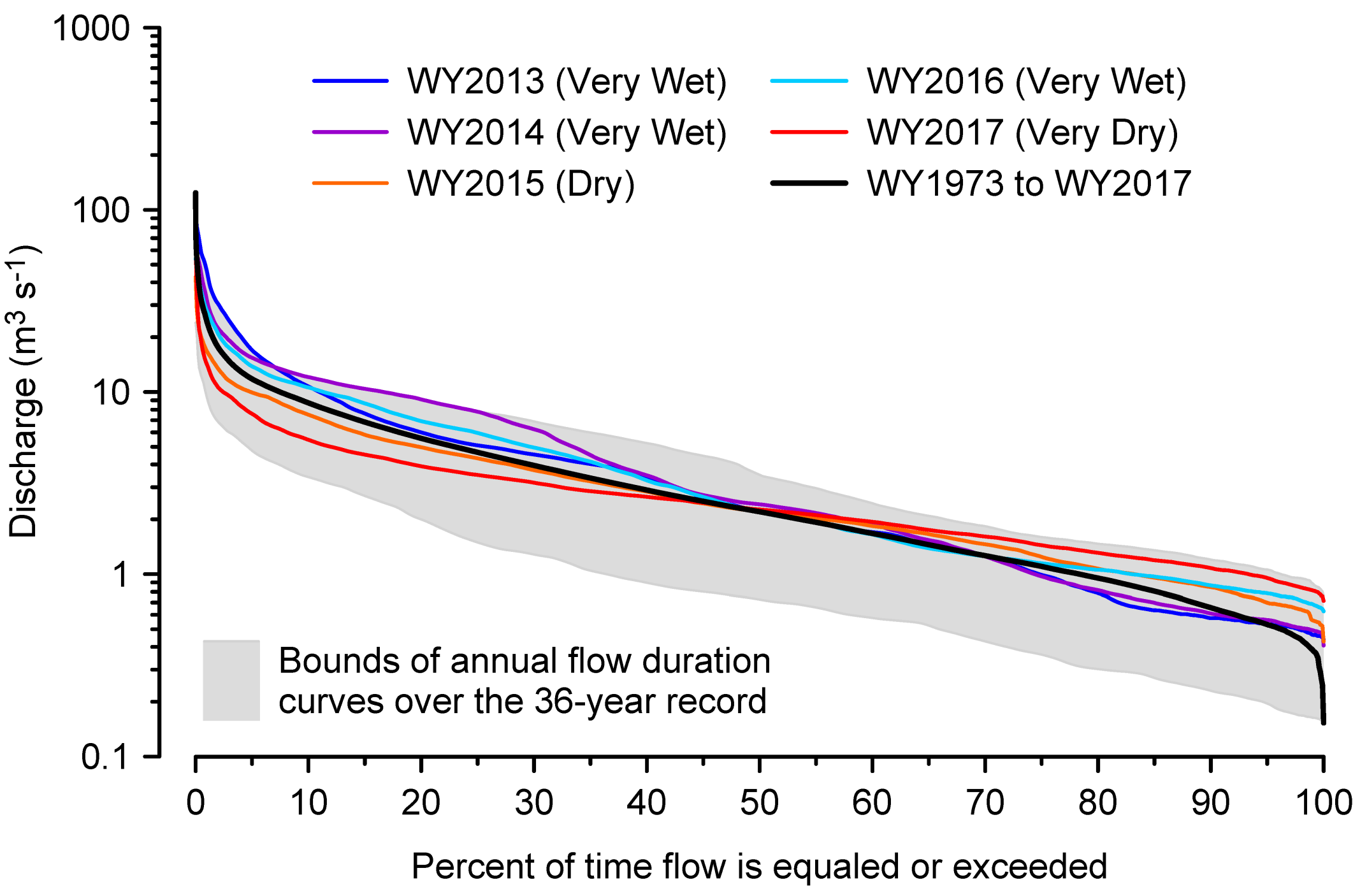


Figure 3. 


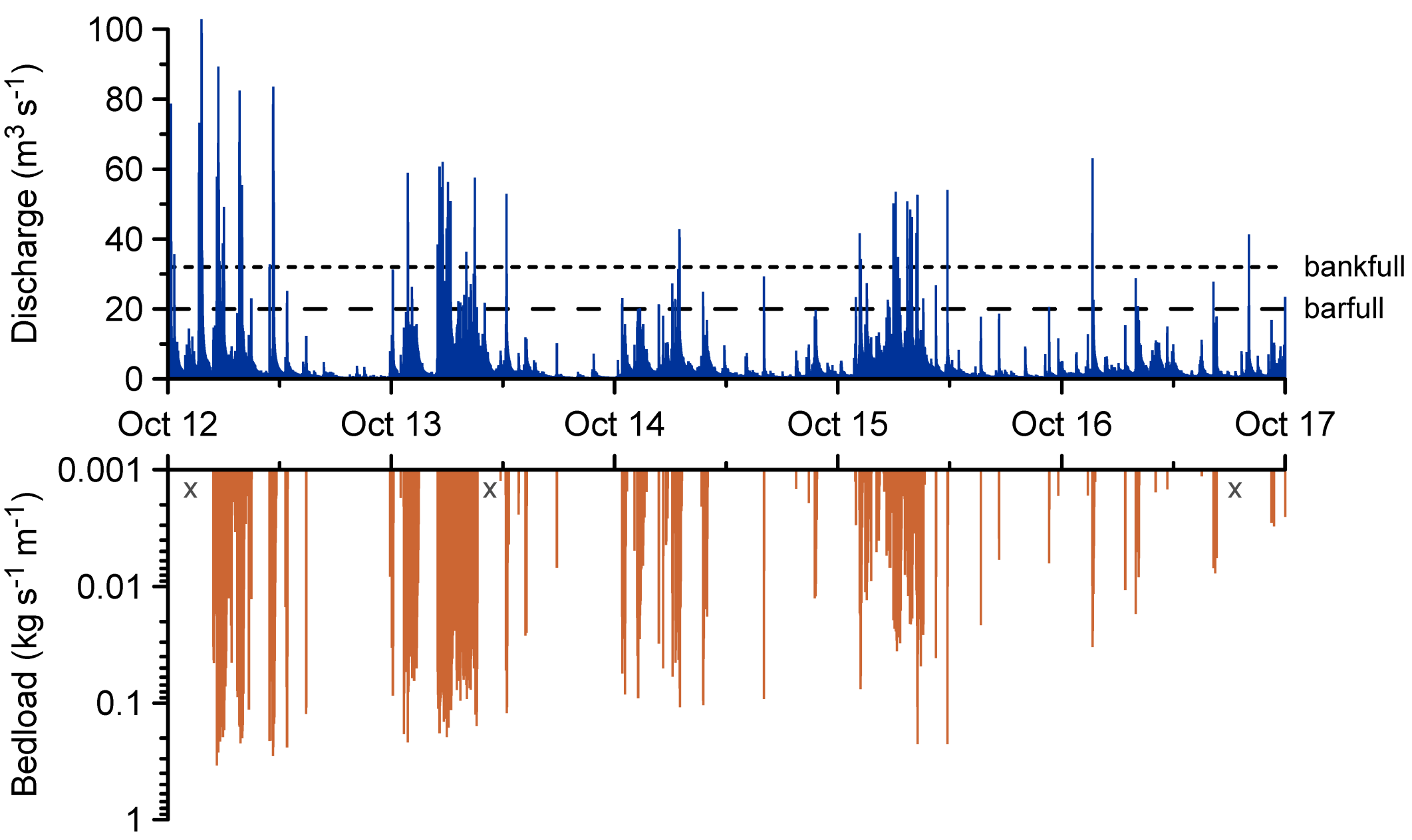


Figure 4. 

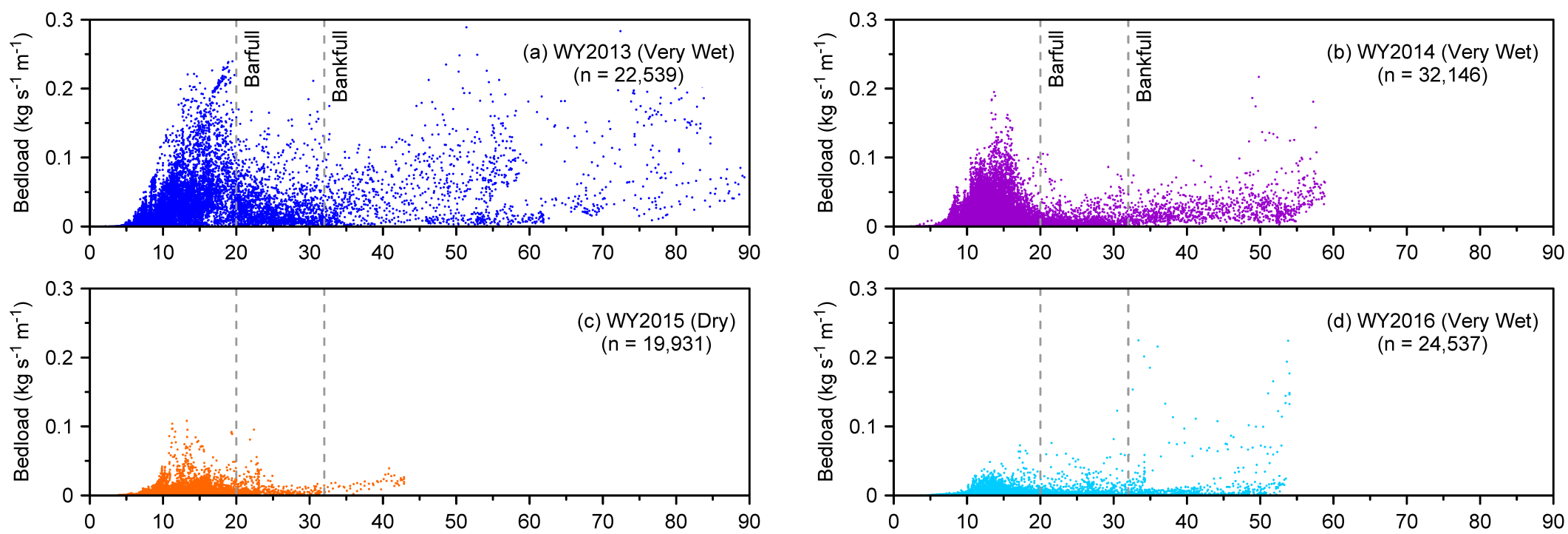

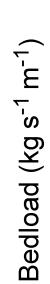
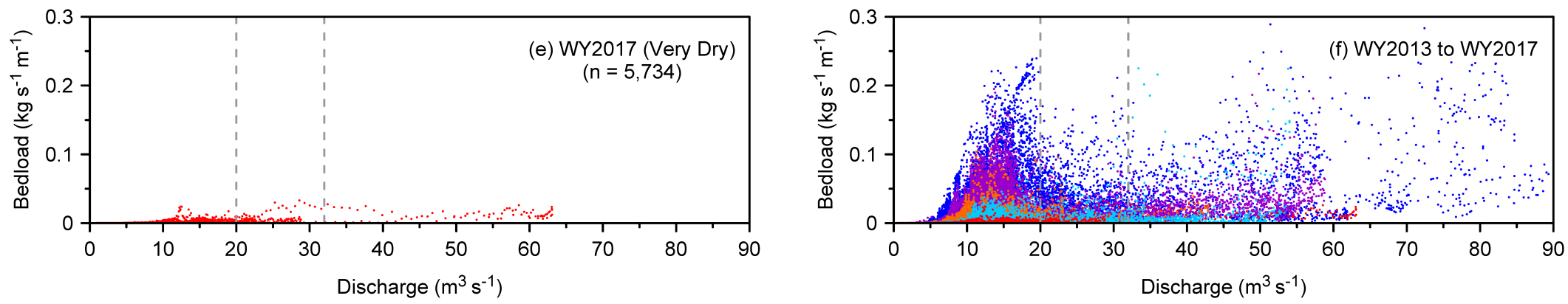
Figure 5. 

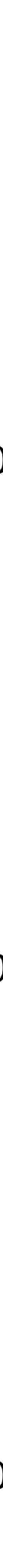
Figure 6. 
(a)

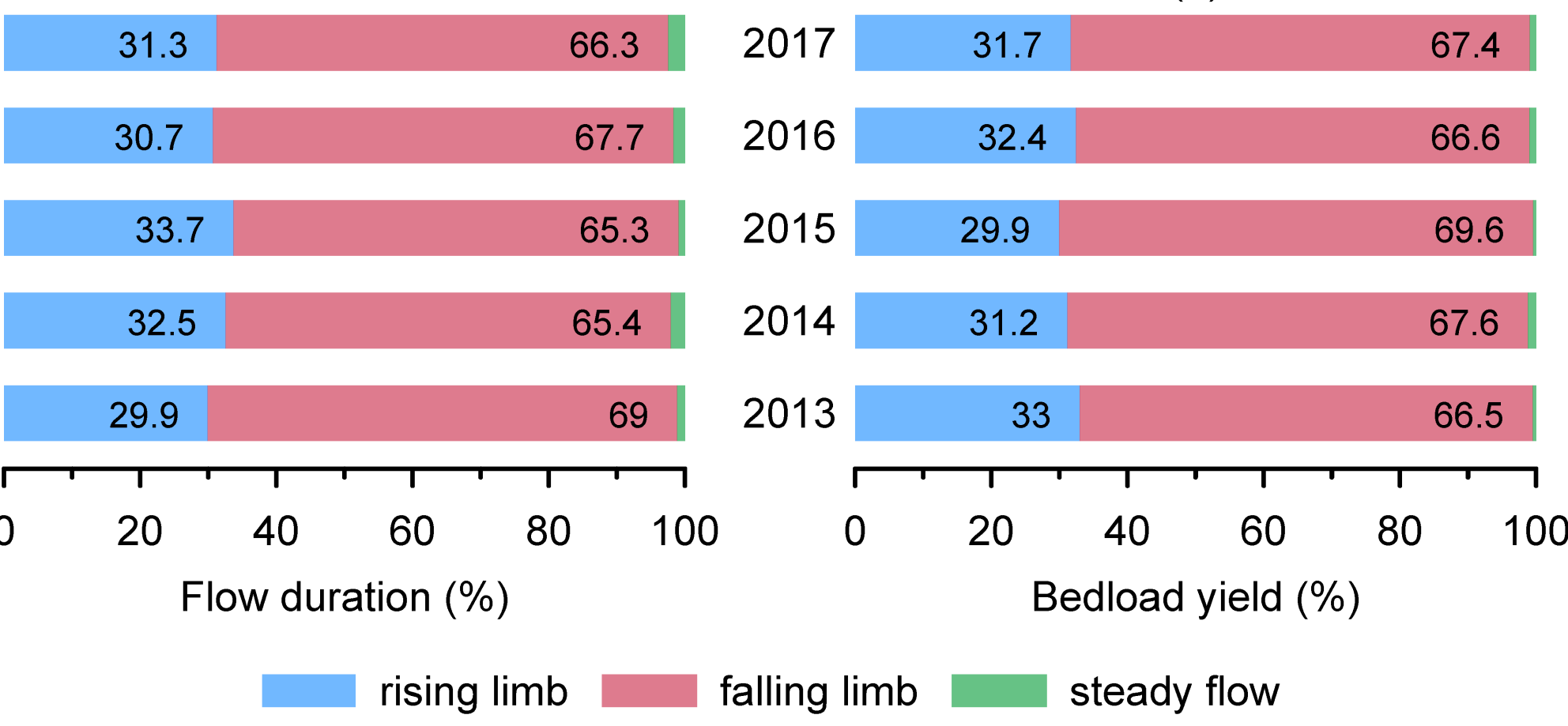


Figure 7. 


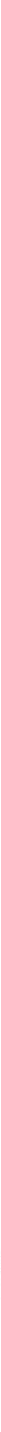


Figure 8. 
Figure 9. 


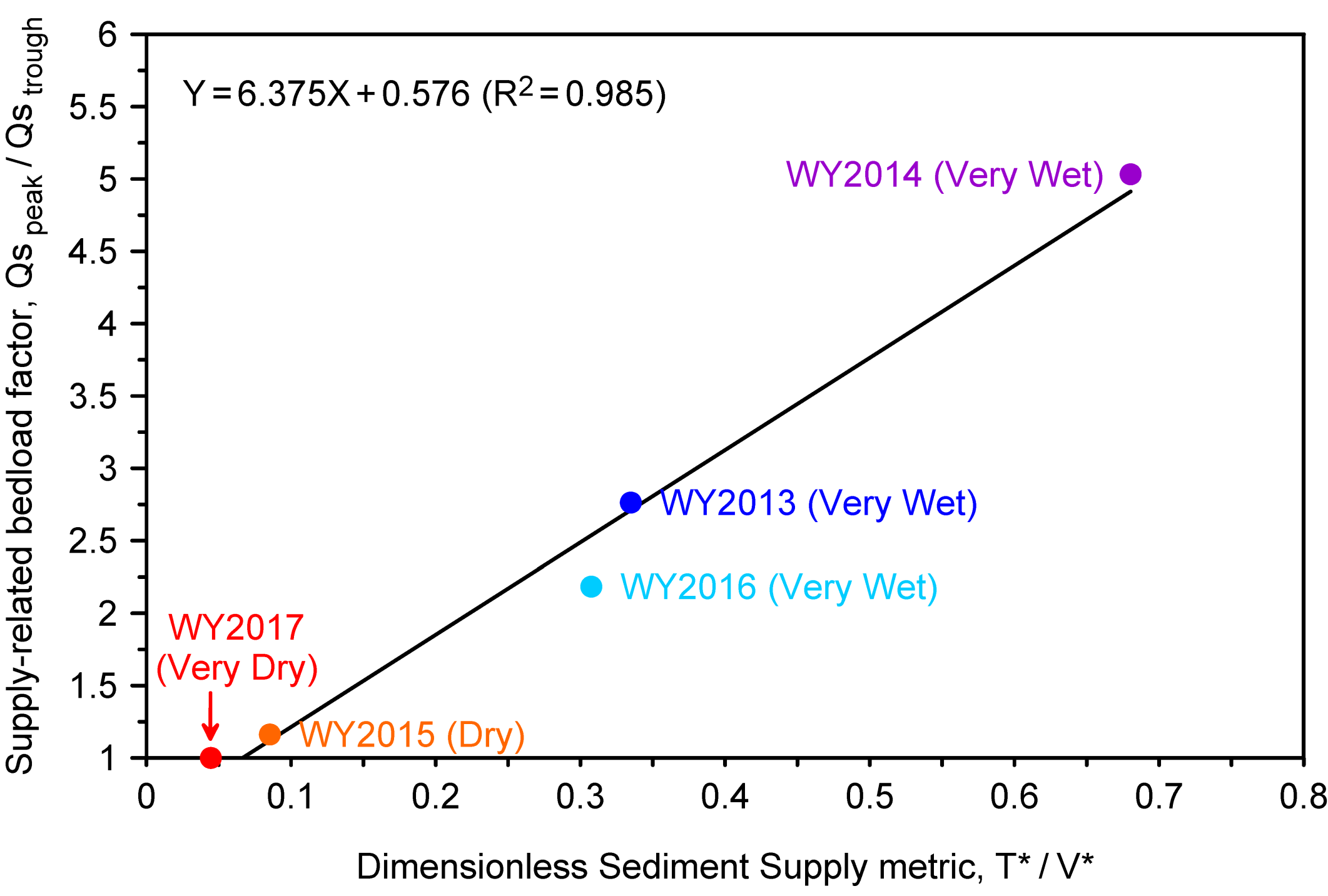


Figure 10. 


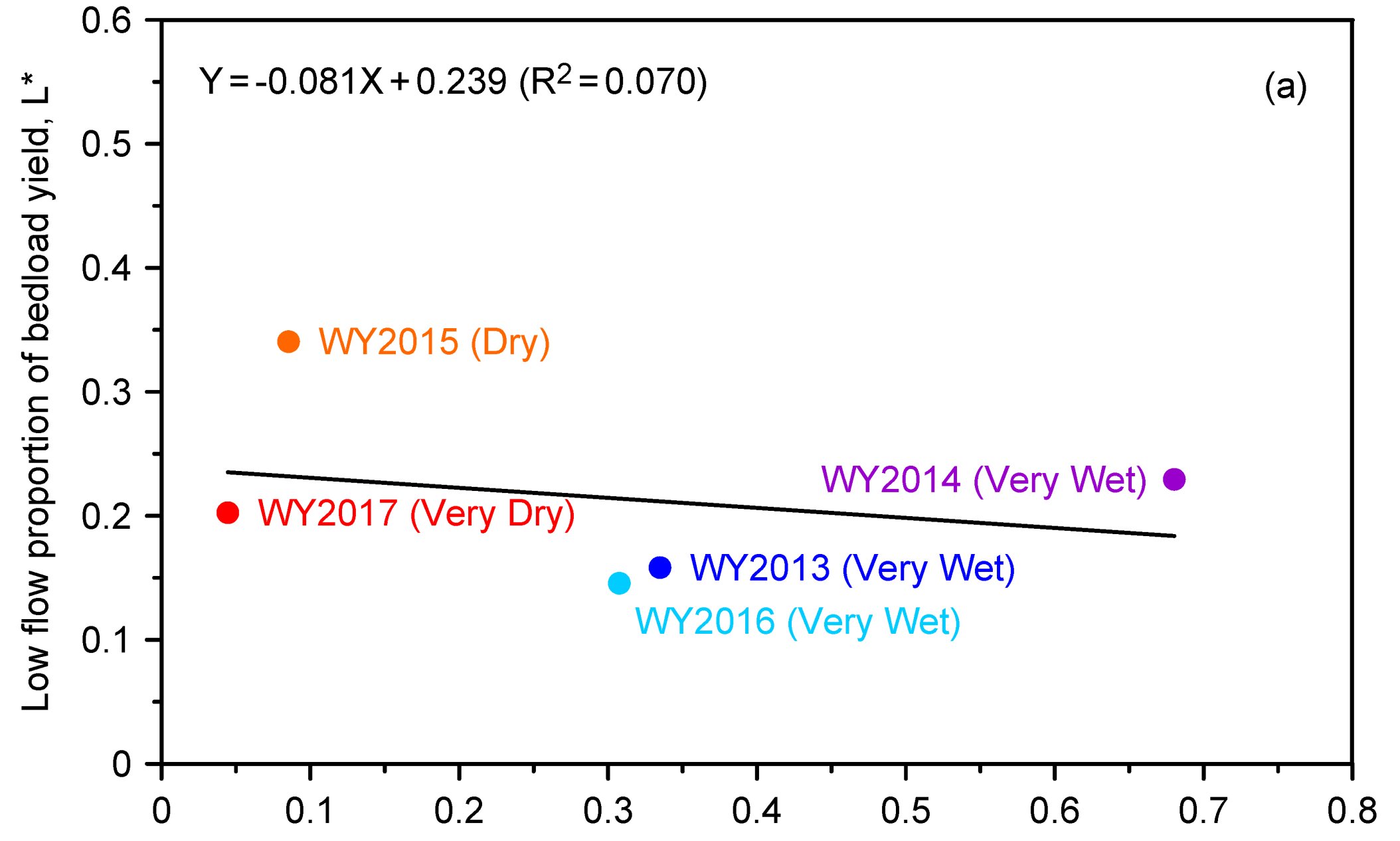

Dimensionless Sediment Supply metric, $\mathrm{T}^{*} / \mathrm{V}^{*}$

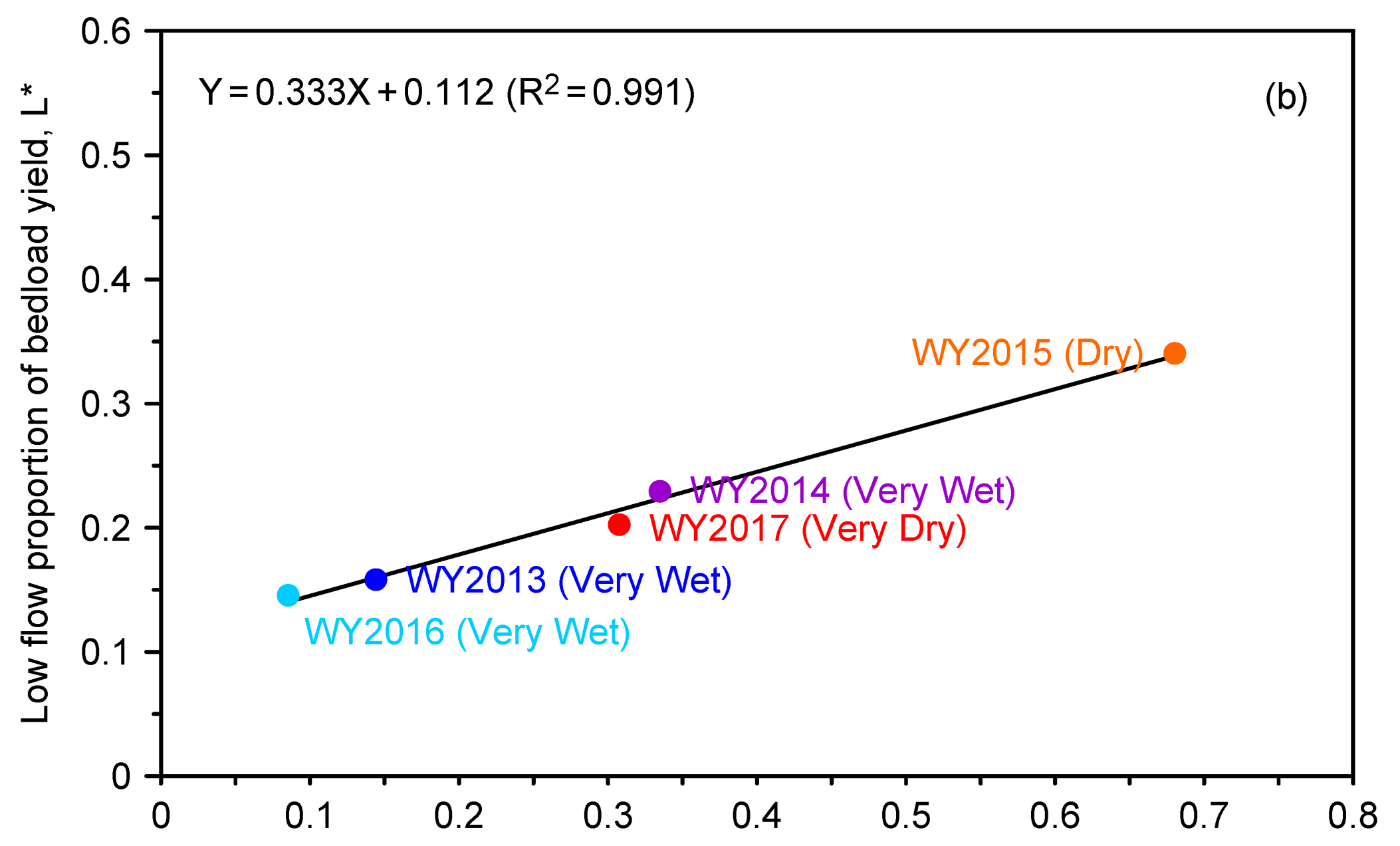

Dimensionless Sediment Supply metric, $T^{*} / \mathrm{V}^{*}$, for previous year 